\title{
Ponte dos Jesuítas, Rio de Janeiro (RJ): uma análise de seus elementos com base na integração de registros textuais, iconográficos e petrográficos
}

Bridge of the Jesuits, Rio de Janeiro (RJ): an analysis of its elements based on the integration of textual, iconographic and petrographic records

http://dx.doi.org/10.1590/1982-02672019v27e06

\section{SORAYA ALMEIDA'}

https: / / orcid.org/0000-0002-7090-780X

Universidade Federal Rural do Rio de Janeiro / Rio de Janeiro, RJ, Brasil

RESUMO: Considerada a mais importante obra de engenharia brasileira do século XVIII, a Ponte dos Jesuítas, tombada pelo Iphan em 1938, foi construída por religiosos inacianos como parte de um sistema complexo de drenagem e irrigação da Fazenda Santa Cruz, localizada na Zona Oeste da cidade do Rio de Janeiro. $\bigcirc$ trabalho aqui apresentado é o primeiro estudo sistemático dos elementos da ponte, realizado com o objetivo de identificar alterações de seus traços originais por meio da integração de textos, imagens históricas e estudo petrográfico das rochas utilizadas como cantarias. Os resultados permitiram reconhecer sinais de intervenções de diferentes períodos e identificar funções de alguns elementos construtivos da obra.

PALAVRAS-CHAVE: Engenharia Jesuítica. Cantaria. Ponte de Alvenaria. Santa Cruz.

ABSTRACT: Considered as the most important Brazilian engineering work of the 18th century, the Jesuits Bridge was built by lgnatian priests as part of a drainage and irrigation complex system at Santa Cruz Farm, in the west side of Rio de Janeiro City. This work is the first systematic study of the bridge with the intent of identifying changes of original features by integrating texts, images and petrographic analyses of rocks used as stonework. The results show that interventions occurred at different times and allowed to identify the functions of some of the bridge's constructive elements.

KEYWORDS: Jesuitic Engineering. Stonework. Masonry Bridge. Santa Cruz.

1. Geóloga pela Universidade Federal Rural do Rio de Janeiro (UFRRJ), mestra em Geologia pela Universidade Federal do Rio de Janeiro (UFRJ) e doutora em Geociências (Mineralogia e Petrologia) pela Universidade de São Paulo (USP). Atualmente é professora adjunta da UFR R . E-mai 1 : <salmeida1966@gmail.com> 
2. Cf. Gama (1875).

3. Cf. Friedman (1999).

4. Cf. Gama (1875).

\section{INTRODUÇÃO}

A Ponte dos Jesuítas, tombo $n^{\circ} 3$ do Instituto do Patrimônio Histórico e Artístico Nacional (Iphan), está localizada em Santa Cruz, bairro da Zona Oeste da cidade do Rio de Janeiro. Durante os séculos XVII e XVIII, a região abrigou a sede de uma fazenda pertencente à Companhia de Jesus, cujas terras se estendiam por mais de 1.700 km². A origem dessa imensa propriedade, que iniciava no litoral e finalizava em Vassouras, no Vale do Paraíba, remonta a 1589, quando parte das terras de Guaratiba, pertencentes a Cristóvão Monteiro, foi doada aos religiosos. ${ }^{2}$ Gradualmente, os limites da fazenda foram ampliados por meio de permutas, compras, novas doações e grilagem, transformando Santa Cruz em centro agroindustrial e principal fornecedor de alimentos do Rio de Janeiro. Com a expulsão dos jesuítas em 1759, a fazenda tornouse propriedade da Coroa e, sucessivamente, do Império e da República, entrando posteriormente em decadência, com sua produção jamais atingindo novamente o nível alcançado pelos inacianos, que faziam uso das mais modernas técnicas agropecuárias conhecidas no período. ${ }^{3}$

Do litoral às franjas da Serra do Mar, as terras da fazenda ocupavam uma planície pantanosa, transformada pelos jesuítas em áreas produtivas por meio do primeiro projeto de hidráulica agrícola do Brasil, que, baseado em técnicas holandesas, envolveu a abertura de quilômetros de canais centrais e secundários que drenavam a baixada entre Santa Cruz, Itaguaí e Piranema, interligando os principais rios da região. Os canais de maior porte, conhecidos como Valas do ltá e São Francisco, margeavam ambos os lados do rio Guandu e ultrapassavam dez quilômetros de comprimento, servindo também como via de transporte de produtos até o porto da llha da Madeira, na Baía de Sepetiba. Diques foram levantados ao longo das margens do Guandu, com o objetivo de proteger os campos de alagamentos durante as grandes cheias. Contudo, apesar do bom resultado do sistema de escoamento durante as enchentes, nos períodos de seca os canais drenavam os pastos em demasia. Como solução, os religiosos instalaram nas barragens um sistema de comportas, conhecidas como "óculos", devido ao seu formato ovalado, que permitia a retirada do excesso de água durante as enchentes e sua retenção durante as estiagens. Na região do Frutuoso, hoje conhecida como bairro Jesuítas, foi construída uma ponte sobre o rio Guandu, também dotada de óculos capazes de reter as águas e desviátas para a Vala do ltá quando necessário. ${ }^{4}$

Após a expulsão dos jesuítas em 1759, os trabalhos de manutenção dos canais e diques passaram a ser negligenciados, e a região retornou ao seu estado pantanoso, transformando-se em uma área de malária epidêmica. Os antigos canais 
começaram a ser recuperados a partir de 1933 sob a coordenação da Comissão de Saneamento da Baixada Fluminense. As valas jesuíticas foram dragadas e retificadas, e novos canais e diques construídos. ${ }^{5}$ Em 1932 o leito do rio já havia sido desviado, e as águas que corriam sob a ponte jesuítica passam agora sob a ponte Lindolfo Collor, na estrada do Curtume, a menos de cem metros da anterior.

A dedicação de historiadores e de membros da comunidade evitou a demolição da ponte durante as obras de saneamento e, em 1938, ela foi tombada por meio de um processo que também envolveu os Arcos da Lapa e o Marco da Fazenda Real de Santa Cruz. ${ }^{6}$

Ao visitar o monumento em 2009, a autora observou heterogeneidade nos tipos de rochas que a compunham, o que sugeria a substituição de componentes e, por conseguinte, alterações das características originais. Com o objetivo de investigar essa hipótese, iniciou o estudo das pedreiras coloniais da região de Santa Cruz e das cantarias que compõem a ponte. Paralelamente, reuniu e analisou registros textuais e iconográficos que descrevem a Ponte dos Jesuítas em diferentes momentos históricos. Os resultados obtidos são aqui apresentados e compõem o primeiro estudo sistemático dos elementos constituintes da Ponte dos Jesuítas.

\section{DESCRIÇÕES E REGISTROS TEXTUAIS DE INTERVENÇÕES}

A mais antiga descrição da Ponte dos Jesuítas é encontrada no poema científico "De rusticis rebus brasiliae carminu", do padre português José Rodrigues de Melo, publicado em 1781, em conjunto com os poemas do jesuíta carioca Prudêncio de Amaral.7 A obra, traduzida do latim por João Gualberto Ferreira dos Santos Reis em 1817, foi publicada no século XX pela Academia Brasileira de Letras, sob o título Geórgicas brasileiras, ${ }^{8}$ e vertida para prosa em linguagem moderna por Raul José Sozim e Sérgio Monteiro Zan. 9 Segundo os autores, o padre poeta nasceu na cidade do Porto em 1723, tendo passado parte da sua vida como professor no Colégio de Paranaguá, no Paraná. Obrigado a interromper sua carreira devido à expulsão dos jesuítas, embarcou para o Rio de Janeiro em 1760, deixando o Brasil poucos dias após desembarcar na capital fluminense. É provável que seu contato com o monastério de Santa Cruz date dessa passagem pela cidade, ocorrida oito anos após a inauguração da Ponte dos Jesuítas.

Os versos com referências a Santa Cruz fazem parte do Canto Quinto, intitulado "Da criação de boi no Brasil", e discorrem sobre o sistema de drenagem
5. Cf. Alonso (1960).

6. Cf. Carrazzoni (1987).

7. Amaral; Melo (1941).

8. Silva (1941).

9. Sozim; Zan (1997). 
10. Amaral; Melo (1941, p. 238)

11. Freitas (1985a) da fazenda. Exemplo de reação estética ao uso da tecnologia para melhorar a condição humana, o poema compara os férteis campos da região aos pântanos preexistentes, quando o rio Guandu (Ganduzio) alagava periodicamente a planície, levando os animais à morte. A seguir é apresentado o trecho em questão, traduzido por Santos Reis e transcrito por Silva:

O poema informa que a ponte possui quatro arcos constituídos por rochas ("lapídea ponte" significando ponte de pedra) e cantarias ("pedra viva", expressão que designa uma rocha lapidada para servir na construção de uma obra, em oposição a "pedra morta", uma rocha não trabalhada), e que dois dos arcos eram dotados de comportas de ferro ("ferrado obstáculo"). Tais expressões são usadas como analogias na filosofia cristã. Segundo Freitas, os óculos não seriam de ferro, mas de madeira, movimentados por meio de correntes de ferro que ainda estavam em uso durante o Segundo Império, como comprovam os livros contábeis da antiga superintendência, que registram a compra de graxas para lubrificação das "ferragens e encaixes" dos óculos. "1

Uma descrição da ponte na passagem do século XVIII para o XIX é encontrada nas memórias do engenheiro militar Manoel Martins do Couto Reis. $\bigcirc$ texto, que relata seu período como administrador da fazenda entre 1793 e 1804, foi publicado 81 anos depois pela Revista do Instituto Histórico e Geográfico do Brasil:

De cantarias bem trabalhadas e unidas pelas juncturas, construíram no Guandú uma lindíssima ponte, apoiada sobre arcos desiguais; mas com tão discreta proporcionalidade, que pelos seus centros as águas deste rio passassem livremente, enquanto corressem nos limites de seu álveo. Umas comportas inventadas e dispostas, segundo os misteres, em que serviriam, eram como feixes graduais e designados a reter as águas sobejas, ampliar o curso das precisas, e fazer retroceder as surpérfluas para o Taguay, na conformidade que tenho mostrado. Sobre a abobada, ou pavimento superior desta 
ponte não acabada, ainda vemos restos de enfeites, e pequenas colunatas, que guarneciam uma espécie de parapeito, como também uma porção de tarjeta lavrada de relevo, com a seguinte inscrição em um elegante dístico, por baixo dessas sagradas letras $[\ldots] \cdot .^{12}$

Pelo texto tem-se conhecimento de que as comportas estavam instaladas nos arcos laterais, permanecendo os arcos centrais continuamente abertos. $\bigcirc$ uso da palavra "restos" para referir-se aos adornos e colunatas revela que, em 1804 - ano em que Couto Reis deixou de administrar a fazenda -, os ornamentos da ponte já estavam danificados. Observa-se que, na percepção do autor, a ponte não estava finalizada.

Couto Reis também descreve duas eclusas nos diques, que permaneciam abertas nos meses de seca e fechadas nos períodos de enchentes. A primeira, situada na taipa do Frutuoso, era conhecida como Óculo do Frutuoso, ou Óculo dos Espanhóis. ${ }^{13}$ A segunda, dita Óculo do Candinho, fazia a ligação entre o rio Guandu e a Vala de São Francisco. Ambas eram estruturadas em pedra e possuíam registros graduados:

De pedra e cal erigiram dois grandes óculos, com suas comportas e registros muito bem graduados, e contíguos aos rios, de onde (quando convinha) soltavam os volumes de águas necessárias, encaminhadas por duas valas, passando d'estas a outras, a circular, e fecundar o campo. ${ }^{14}$

Alterações no desenho original da ponte estão indicadas em livro contábil de 1847 da Superintendência da Fazenda Imperial. ${ }^{15}$ Segundo o registro, o artesão Antonio Francisco Rios recebeu o pagamento pelo serviço "que fez nos enfeites da inscrição de pedra que tem de ser colocada na Ponte do Rio do Curtume", como então era conhecida a Ponte dos Jesuítas, situada nas proximidades do Curtume Imperial. Novas intervenções ocorreram em 1854, quando o engenheiro-coronel Conrado Jacob Niemeyer, designado coordenador das obras de reconstrução das pontes da fazenda, caiou e reparou as "partes mais grossas" da Ponte dos Jesuítas.

Saldanha da Gama, administrador da fazenda entre 1869 e 1872, destaca o uso estético das pedras na construção:

Construíram uma ponte sobre o rio Guandu, perto da olaria, toda de cantaria, apoiada em arcos desiguais. Com um adequado sistema de comportas conseguiam eles fechar
12. Couto Reis (1885, p. 156).

13. Cf. Gama (1875).

14. Couto Reis (1885, p. 156).

15. Freitas (1985a). 
16. Gama (1875, p. 224)

17. Couto Reis (1885, p. 157); Gama (1875, p. 225). o leito do rio ao curso das águas, ora totalmente, ora em parte; ou diminuíam a vontade o volume de água que descia, ou aumentavam, ou interrompiam, completamente a comunicação entre as partes superior e inferior do rio, situadas dos dois lados da ponte. Se nas épocas das enchentes as águas assoberbavam-se, ameaçando de inundação dos terrenos de uma e outra margem, os jesuítas fechavam as comportas, e as águas diante deste obstáculo voltavam sobre si, e escoavam pela saída fácil do canal até o Rio Grande e deste até o mar. [... . A porção superior, toda de pedra, é algum capricho na construção: colunas, relevos, partes esculpidas, pavimento calçado e abaulado; e mais se realça pelo pensamento, em língua latina, que os jesuítas fizeram gravar na principal pedra da parede da direita. ${ }^{16}$

Na descrição de Saldanha, todos os arcos são dotados de comportas, sendo possível a completa obstrução do fluxo das águas. Tal informação está em desacordo com os relatos do padre José Rodrigues e de Couto Reis, segundo os quais os túneis centrais eram desprovidos de óculos. Desta forma, ou o sistema foi modificado entre as duas administrações, ou trata-se de um equívoco de Saldanha Gama.

Saldanha Gama afirma que a porta do Óculo dos Espanhóis era de ferro - "Por ocasião das enchentes fechavam eles os óculos dos Espanhóis por meio de uma porta de ferro" -, mas não faz referência ao material usado nas comportas da Ponte dos Jesuítas.

Gama e Couto Reis apresentam a seguinte transcrição da epígrafe gravada em relevo no dístico da ponte:

HS

FLECTE GENU, TANTO SUB NOMINE, FLECTE VIATOR

HIC ETIAM REFLUA FLECTITUR AMNIS AQUA ${ }^{17}$

Sendo IHS o emblema da Companhia de Jesus Ulesus Hominibus Salvatoren - Jesus Salvador dos Homens). De acordo com Saldanha Gama, a epígrafe estava gravada "na principal pedra da parede da direita" e, segundo Couto Reis, em "uma porção de tarieta lavrada de relevo" "em um elegante dístico por baixo destas sagradas letras".

Américo Netto, membro da Comissão de Estudos da Associação de Estrada de Rodagem, ao visitar a ponte em 1925, constatou que pouco restava das colunas originais, sem especificar o número exato de colunas preservadas. $\bigcirc$ autor assim descreve a ponte: 
[...] verdadeira maravilha arquitetônica do século XVIII duplicada de portentosa realização da engenharia hidráulica colonial. Construída em 1732, ostenta num escudo, ladeado de colunas, que se defrontam, lado a lado em fileiras normais ao rio [...]. Cada uma dessas colunas eleva-se, bem quadrada, com uma pinha encabeçando-a. Algumas delas caíram, outras foram criminosamente arrancadas. Restam apenas poucas...

A ponte é de fato, uma represa. No paredão vertical que desce da superestrutura abaixo do nível das águas, aprofundando-se até não se sabe aonde, há quatro arcadas, onde corriam portas de subir, e descer, regulando o regime de águas baixadas. ${ }^{18}$

E apresenta uma transcrição distinta para a legenda em latim:

\author{
FLECTE GENUA TANTO SUB \\ NOMINE FLECTE \\ VIATO HIC ETIAM REFLUA FLECTITUR \\ AMNIS ACQUA \\ I. H. $S^{19}$
}

Assim como Netto, Silva relata em 1934 que, quando visitou a ponte em 1927, existiam poucas colunas, e as restantes estavam completamente caiadas, com aparência de recém-reconstituídas. ${ }^{20} \bigcirc$ autor atenta para o equívoco de Américo Netto na disposição das palavras e na grafia de genua acqua, observando que a data e as iniciais $\mid H S$ estariam sob uma cruz, associadas em um escudo, enquanto a legenda estaria "embaixo do escudo em uma espécie de faixa" com as palavras dispostas em apenas duas linhas. Tal descrição de Silva está de acordo com a configuração atual do dístico. Mas, assim como Américo Netto, Silva reconhece o ano de 1732 na inscrição em alto-relevo, e não 1752, como correntemente aceito.

Com o início das obras de saneamento da Baixada de Sepetiba nos anos 1930, a Ponte dos Jesuítas esteve em vias de ser demolida, pois não suportaria o tráfego de veículos modernos. A fim de evitar sua destruição, a Sociedade Centro Carioca, presidida por Benevenuto Berna, assinou uma petição destinada ao ministro da Viação, José Américo, como publicado em $\bigcirc$ Globo (1931). Também na reportagem o ano 1732 é atribuído à inscrição.

Ferreira ${ }^{21}$ apresenta a seguinte tradução para a frase latina: "Curva o joelho sob tão grande nome, ó viajante, curva;/ A refluente água do rio aqui também se curva".

Segundo Silva, 22 o latinista Júlio Barata, fazendo uso de diferentes vocábulos, atribui à frase o mesmo significado e atenta para o desaparecimento da letra r no vocativo viator, que aparece completo nas transcrições de Saldanha 
23. Padberg-Drenkpol (1937, p. 19).

24. Padberg-Drenkpol (1937, p. 20)

25. Livro (1938).

26. Corrêa (1939, p. 191).

27. Freitas (1985b)
Gama e Couto Reis: "Dobra os joelhos ante tão grande nome, dobra, ó viandante;/ Aqui também recuando as aguas do rio se dobram".

Padberg-Drenkpol, ex-jesuíta e professor da Universidade do Brasil, descreveu a ponte, revelando que, à época em que a visitou, era ainda possível observar os caixilhos das comportas, cujo mecanismo era acionado na parte superior:

[...] um sólido dique de alvenaria e cantaria, interrompido por quatro túneis ou vãos abobados, que do lado superior se podiam fechar por outras tantas comportas ou adufas. Vem-se ainda os encaixes em que estas corriam. Subimos ao pavimento superior prolongado de Sul a Norte por entre os dois parapeitos laterais de alvenaria, enfeitados com quatro colunas cada um. Entre as duas colunas intermedias a leste, a montante do rio, eleva-se uma pedra esculpida, mostrando no centro o símbolo do nome sublime de Jesus: $\mid H S$ encimado o $\mathrm{H}$ de uma cruz, com a data sotoposta de 1752. Em baixo uma fita ornamental exibe gravado o seguinte dístico $[\ldots]^{23}$

E apresenta elegante tradução para a inscrição: "Dobra o joelho sob tão grande nome, dobra viajante;/ Aqui também se dobra o rio em água refluente" ${ }^{24}$

No ano seguinte, o Livro do Tombo do Iphan assim descreve o monumento:

Ponte-comporta em cantaria, edificada pelos jesuítas, em 1752, em suas terras de Santa Cruz, com o fim de regularizar o curso do Rio Guandu, desviando parte de suas águas por um canal artificial, para o Rio Itaguaí. No centro de um dos lados do guarda-corpo, existe uma cartela de feição barroca. Estrada do Curtume, Santa Cruz - Rio de Janeiro - R.25

Corrêa ${ }^{26}$ apresenta uma breve descrição da ponte, por ele visitada em 1935: "A ponte colonial pesada era toda de pedra, com colunas, relevos, partes esculpidas, pavimentos calçados e abaulado e tinha a inscrição na principal pedra direita".

Obras de restauração foram realizadas no monumento nos anos 1950, na época do bicentenário de sua construção. Segundo Freitas, o contratante responsável pelo serviço enviou um único pedreiro, que usou cimento para revestir as partes corroídas, sem estudos técnicos ou acompanhamento dos serviços por parte do Iphan. ${ }^{27}$ As obras foram encerradas em 1953 e, após quatro anos, a ponte estava novamente danificada, como mostra o relato de Abreu: 
[...] invadida pelo mato e deteriorada pela ação do tempo. É uma curiosa obra que data de dois séculos numa escultura no granito de grão fino contendo uma inscrição em latim de tema religioso. ${ }^{28}$

A descrição de Abreu é a primeira a especificar o tipo de rocha utilizada na inscrição. Em 1985, Freitas ${ }^{29}$ informa ser de pedra lioz a faixa e o brasão que contém o símbolo da Companhia de Jesus:

[...] a letra em questão não caiu, não foi arrancada e nem sofreu qualquer atentado material, afirmações estas impossíveis de acontecer, pois a inscrição em apreço, é toda esculpida em baixo relevo na própria cartucha, toda ela de "pedra de Lioz".

Em 1963, novamente "em ruínas", a ponte sofre novas reformas. ${ }^{30}$ Quatro anos depois, o jornal $\bigcirc$ Globo denuncia o estado de abandono do patrimônio, então invadido pelo mato e exibindo poucas das colunas originais, quase todas substituídas por colunas de concreto armado. ${ }^{31}$ Nesse mesmo ano, a Comissão do Patrimônio visita o local para avaliar a possibilidade de construir um lago em seu entorno, e o professor Marcelo Moreira de lpanema é designado responsável pela elaboração de um projeto de reconstrução "o mais fiel possível" da antiga ponte. ${ }^{32}$

Com o título "A Ponte dos Depredadores", O Globo noticia em 1971 o protesto de Trajano Quinhões, diretor do Patrimônio Histórico e Artístico da Guanabara, ${ }^{33}$ a propósito do roubo de partes da ponte depredada, cujas pilastras em cantaria estariam "enfeitando jardins particulares". No ano seguinte, novo projeto de restauração é anunciado. ${ }^{34}$ Em 1980, Pedro Calmon, presidente do Instituto Histórico e Geográfico Brasileiro (IHGB), sugere ao prefeito Júlio Coutinho a recuperação de vários monumentos históricos da cidade, entre eles a Ponte dos Jesuítas. ${ }^{35}$ Cinco anos depois são noticiados vários projetos simultâneos de restauração de monumentos, coordenados pelo engenheiro Emílio Giannneli e seu filho Emílio Alfredo, dentre os quais a Ponte dos Jesuítas, cuja obra teria o maior orçamento. ${ }^{36}$ Em dezembro do mesmo ano, Sérgio Tabet, diretor do Departamento de Parques e Jardins, anuncia a conclusão da obra para o dia seguinte. ${ }^{37}$

No início e no final de 2004, funcionários da Companhia de Limpeza Urbana pintam a ponte e executam pequenas obras de recuperação. ${ }^{38}$ Os parapeitos laterais e as pilastras compostas por alvenarias recebem tinta branca, enquanto as pilastras em cantaria permanecem descobertas. Em abril de 2005, a Ponte dos Jesuítas é gravemente danificada por uma tentativa de roubo. Utilizando um caminhão-guincho, criminosos retiraram duas das colunas de pedra e partes dos parapeitos, expondo blocos de rochas utilizados na construção. ${ }^{39}$ As peças
28. Abreu (1957, p. 245).

29. Freitas (1985'a , p. 216).

30. Será (1963).

31. A Ponte (1967).

32. Patrimônio (1967).

33. A Ponte (1971).

34. Patrimônio (1972).

35. Praça (1980).

36. Querubins (1985).

37. Monumento (1985).

38. A Ponte (2004a); Ponte (2004b).

39. Ponte (2005); Recuperação (2005). 
40. Degradação (2006); Desprezo (2006); Obras (2006); Ponte (2006).

41. Ponte (2007).

42. Memória (2008).

43. Ponte (2008).

44. Cf. Jesus (2013); Cordeiro (2014).

45. Niemeyer (1848).

46. Cf. Freitas (1985b). recuperadas ficaram sob a guarda da Polícia Federal, ${ }^{40}$ e os trabalhos de restauração foram iniciados somente em setembro de 2007, sendo o adiamento creditado à falta de verba e à necessidade de um projeto que atendesse as exigências do Iphan. ${ }^{41}$ A obra, coordenada pela Secretaria de Patrimônio Cultural da Prefeitura da Cidade do Rio de Janeiro, é concluída em julho de 2008. ${ }^{42}$ Nos trabalhos foram realizados espatulamento e lixamento do revestimento com retirada de argamassas "incompatíveis com o substrato original", recuperação e pintura de alvenarias e recomposição de colunas e ornatos faltantes, incluindo a reposição de duas colunas furtadas e a recuperação do brasão. ${ }^{43}$

\section{REGISTROS ICONOGRÁFICOS}

Em sua configuração atual, a Ponte dos Jesuítas tem 25 metros de comprimento e 5 metros de largura (Figura 1). Seu tabuleiro é pavimentado com blocos irregulares de pedras e apoiado sobre quatro arcos, sendo o arco sul o de maior dimensão. Os parapeitos possuem oito colunas ornamentais, dotadas de capitéis e pinhas. $O$ dístico com a frase latina e o brasão jesuítico se encontram no centro do parapeito oeste (Figura 2), ladeados por duas colunas que se confrontam com outro par no parapeito oposto. As demais colunas ornam as entradas sul e norte, cada qual exibindo distância distinta em relação ao centro da ponte (em torno de 12,7 m para as colunas ao norte e $11 \mathrm{~m}$ para as colunas ao sul). A estrutura interna das paredes dos parapeitos e dos muros de tímpano, parcialmente exposta durante as obras de restauração em 2009, é formada por blocos de rochas com intervalos de entre $15 \mathrm{~cm}$ e $25 \mathrm{~cm}$. A face leste da ponte (Figura 3) apresenta cinco talhantes trapezoidais. Em pontes de pedra, a forma dos talhantes a montante era tipicamente triangular, a fim de atenuar a força da corrente de água, diminuindo o impacto sobre os pilares. ${ }^{44} \mathrm{~A}$ forma trapezoidal observada nos talhantes a montante na Ponte dos Jesuítas teria a mesma função.

A imagem mais antiga da Ponte dos Jesuítas é encontrada em planta corográfica de autoria do engenheiro Conrado Jacob Niemeyer. ${ }^{45} \mathrm{O}$ trabalho antecede reformas realizadas na ponte pelo próprio Niemeyer em 1854 e contém um desenho da fachada oeste (Figura 4), tendo ao fundo o antigo palacete do Curtume e o conjunto de edifícios da Olaria Imperial, demolido em 1876. ${ }^{46} \mathrm{~A}$ desigualdade nas dimensões dos arcos, comumente citada nas descrições textuais, é retratada com fidelidade na estampa, na qual o arco mais ao sul exibe maiores dimensões. A imagem de 1848 mostra uma mísula entre os arcos centrais. Essa 
mesma estrutura pode ser observada, já semidestruída (Figura 5), em esboço de Corrêa datado de 1939.47 A forma e posição da mísula junto ao pilar central indica que esta funcionava como talhante de jusante, do qual restam apenas alguns blocos de rochas (Figura 6). Tal talhante tinha a função de evitar a erosão do pilar devido aos turbilhamentos que ocorrem nessa região. Tipicamente, o talhante de jusante era construído como um elemento mais baixo que o talhante de montante, com forma retangular ou arredondada, a fim de impedir a sucção das paredes. ${ }^{48}$

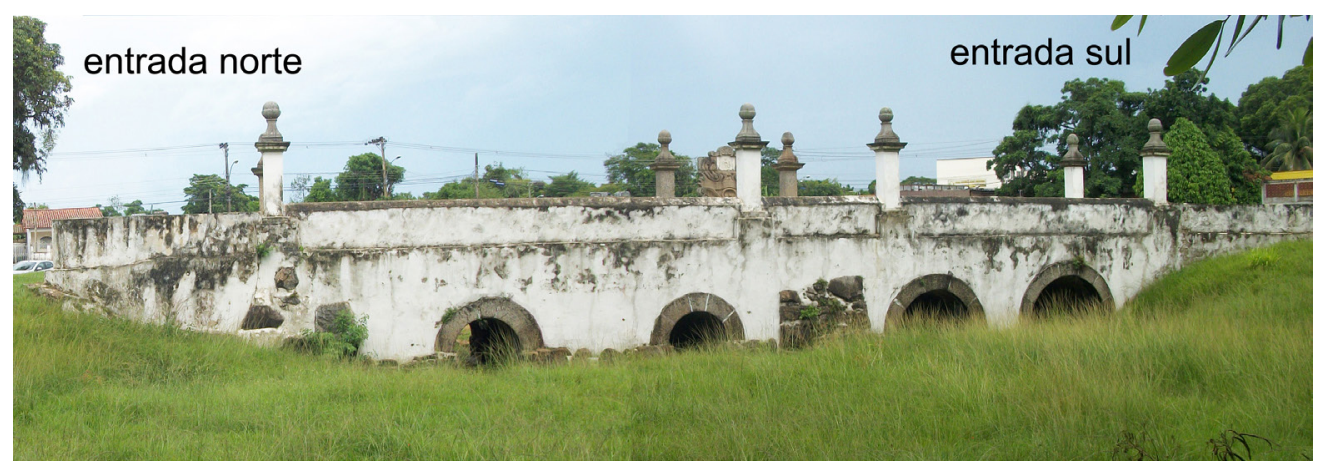

Figura 1 - Vista oeste da Ponte dos Jesuítas, 2018. Fotografia da autora.

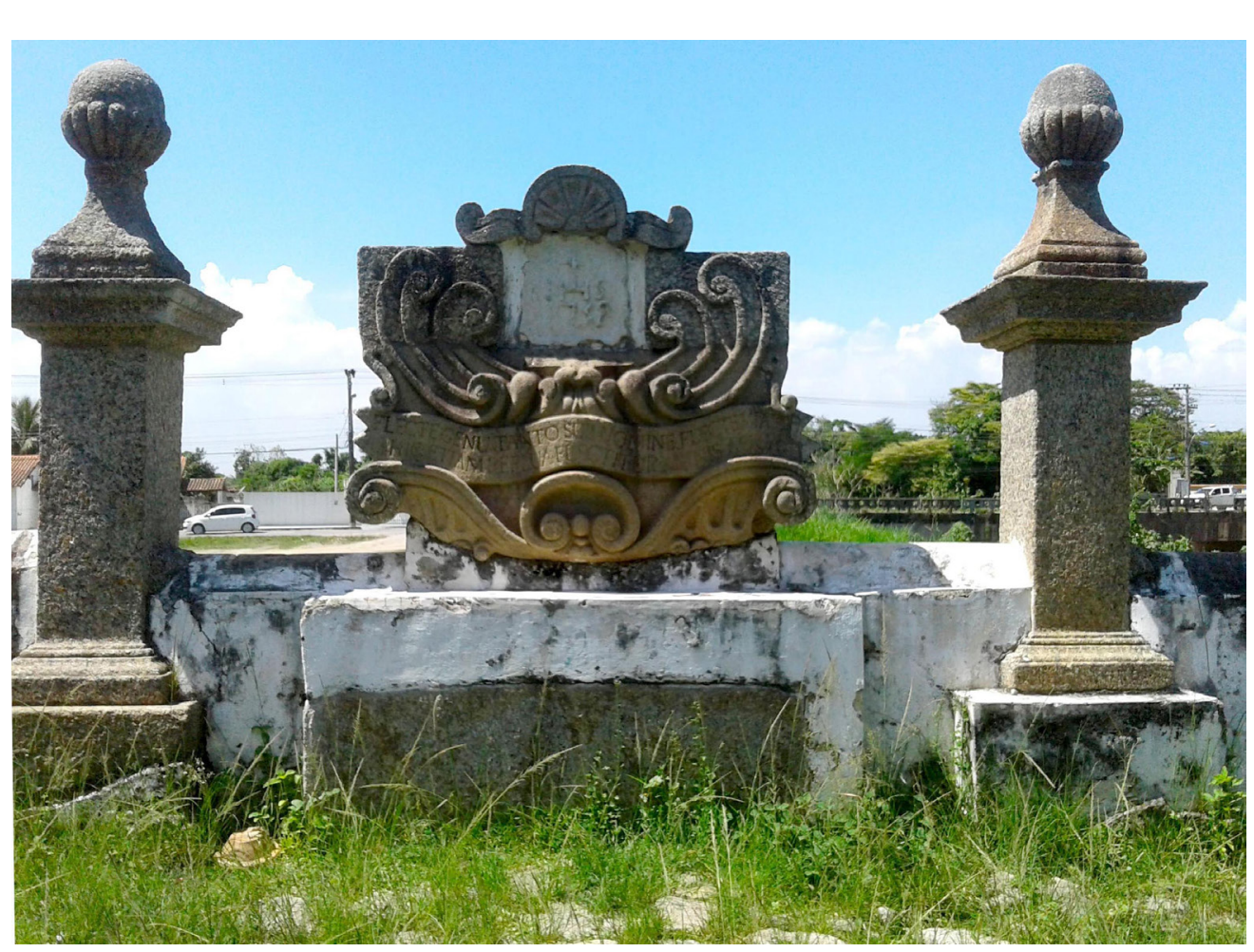

Figura 2 - Dístico e colunas laterais da Ponte dos Jesuítas, 2018. Fotografia da autora.
47. Corrêa (1939).

48. Cf. Cordeiro (2014) 
Figura 3 - Vista leste da Ponte dos Jesuítas, 2018. Fotografia da autora.

Figura 4 - Vista oeste da Ponte dos Jesuítas por Conrado Jacob Niemeyer. Fonte: Niemeyer (1848). Acervo da Biblioteca Nacional.
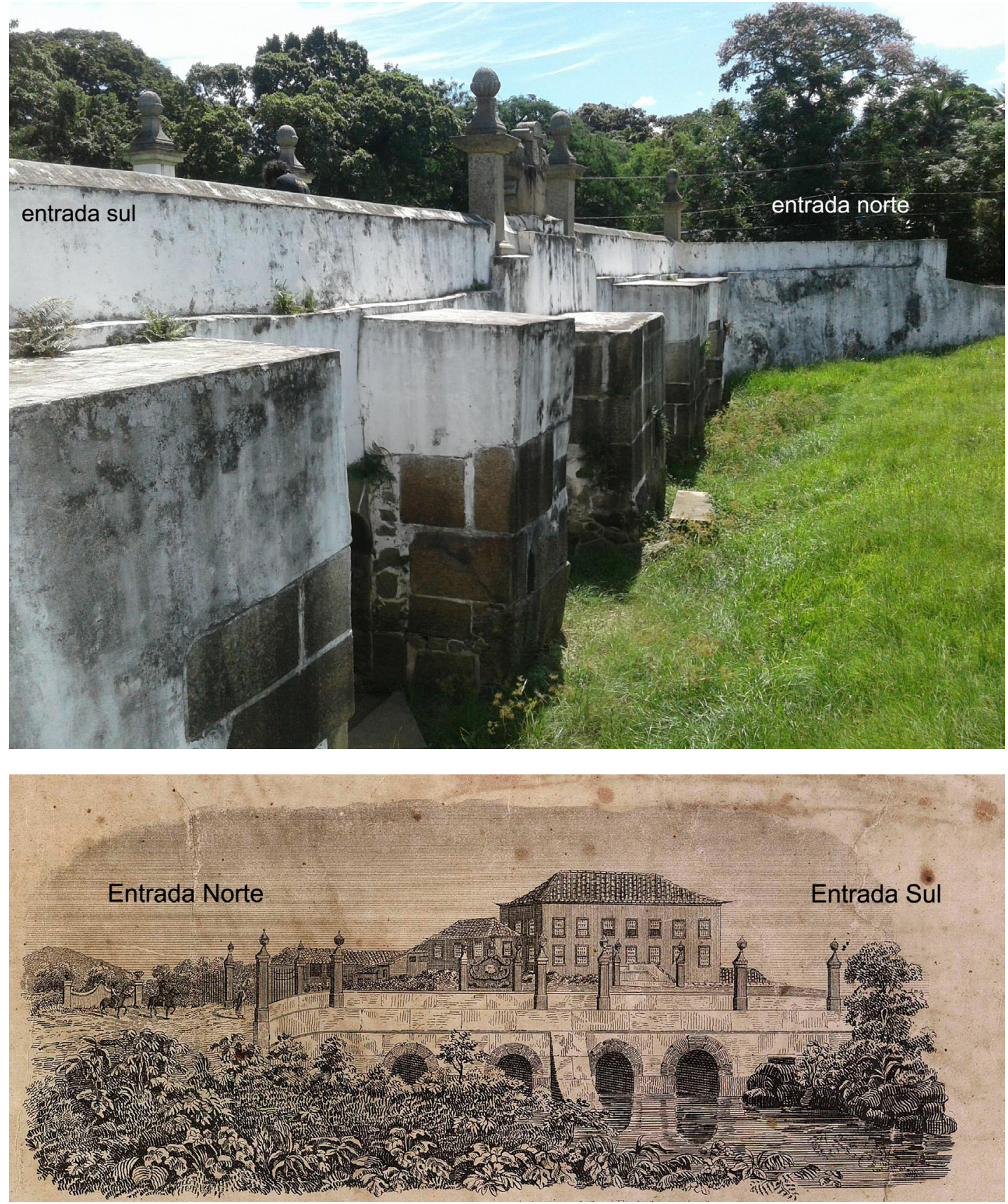

Na representação de Niemeyer, a fachada oeste é revestida por cantarias regulares. É admissível que tal revestimento em pedras tenha de fato existido no passado, pois algumas cantarias ainda são vistas na face leste da ponte, como pode ser observado na Figura 3. Além das atuais oito colunas, a imagem de Niemeyer (Figura 4) inclui mais dois pares no prolongamento dos 
parapeitos, compondo um total de doze colunas. Corrêa, ${ }^{49}$ por sua vez, retrata a ponte com dez colunas (Figura 5), enquanto a fotografia em plano aberto publicada pela Revista da Semana em 1933,50 replicada em artigo de Guimarães em 1940, ${ }^{51}$ exibe apenas oito colunas (Figura 7), número que figura em todas as imagens posteriores. Além de apresentarem número maior de colunas, as imagens de Niemeyer e Corrêa também exibem parapeitos com feições distintas das atuais. Nelas, os parapeitos se prolongam por mais alguns metros (Figuras 4 e 5). É possível reconhecer na fotografia da Revista da Semana ruínas que atestam que o guarda-corpo efetivamente se prolongava além das colunas que hoje marcam a entrada sul da ponte (Figura 7).

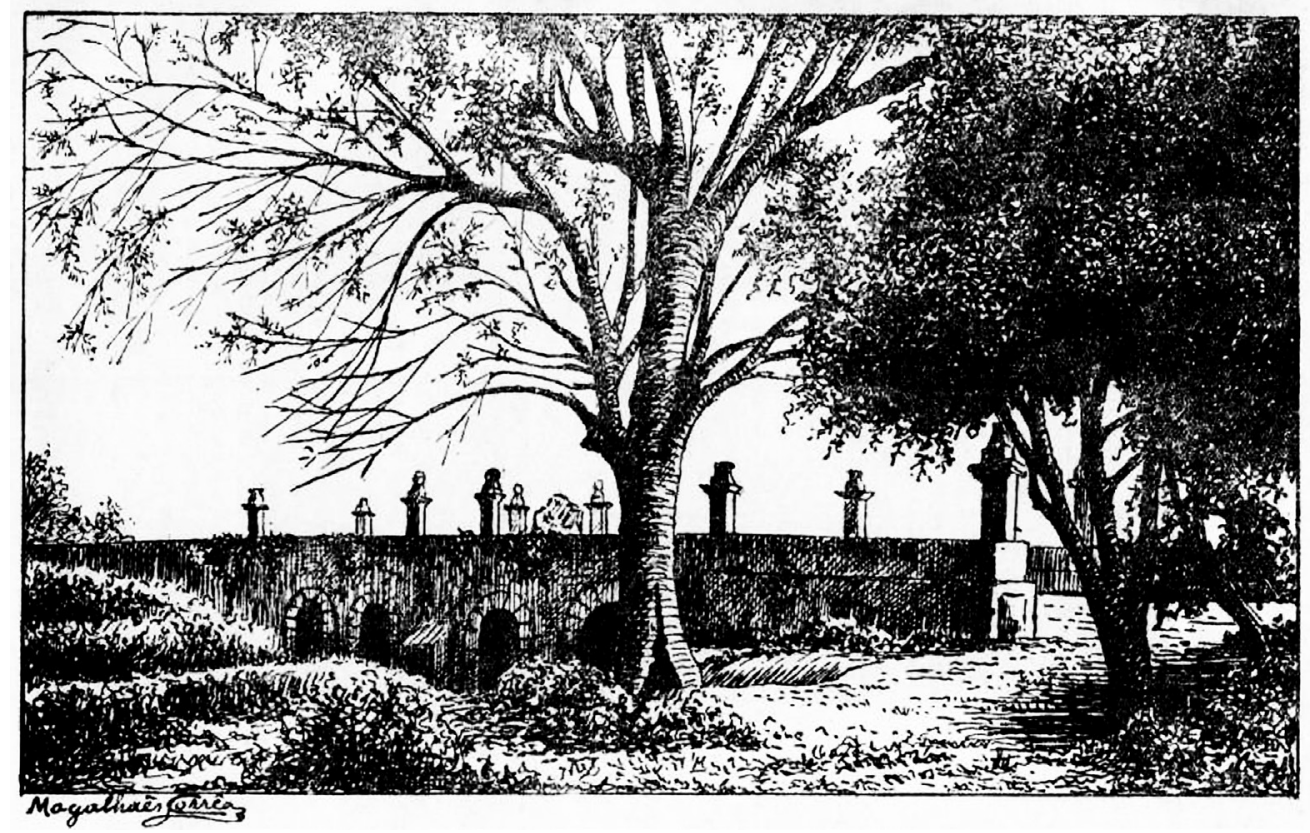

Figura 5 - Ponte dos Jesuítas por Magalhães Corrêa. Fonte: Corrêa (1939).

Assim como foi fiel na representação da desigualdade dos arcos, Niemeyer também retrata com precisão a falta de simetria na distância entre as colunas remanescentes e o centro da ponte, posicionando as do norte a uma maior distância.

A Figura 8 permite comparar a forma das colunas como retratada por Niemeyer, em 1848, e por Corrêa, em 1939, com sua forma atual. Na representação de Niemeyer, as pinhas possuem contorno alongado, e não o arredondado já presente na mais antiga fotografia do dístico encontrada nessa pesquisa (Figura 9), de autoria do engenheiro Américo Netto52, captada em 1925.
49. Corrêa (1939).

50. A Fazenda (1933).

51. Guimarães (1940).

52. Netto (1927). 
53. O Resgate (1927).

54. Ferreira (1929).

55. Freitas (1985a).

56. Niemeyer (1848)

57. Ferreira (1929).

58. A Fazenda (1933).

59. Corrêa (1939).

Figura 7 - Vista leste da Ponte dos Jesuítas publicada na Revista da Semana. Fonte: A Fazenda (1933).

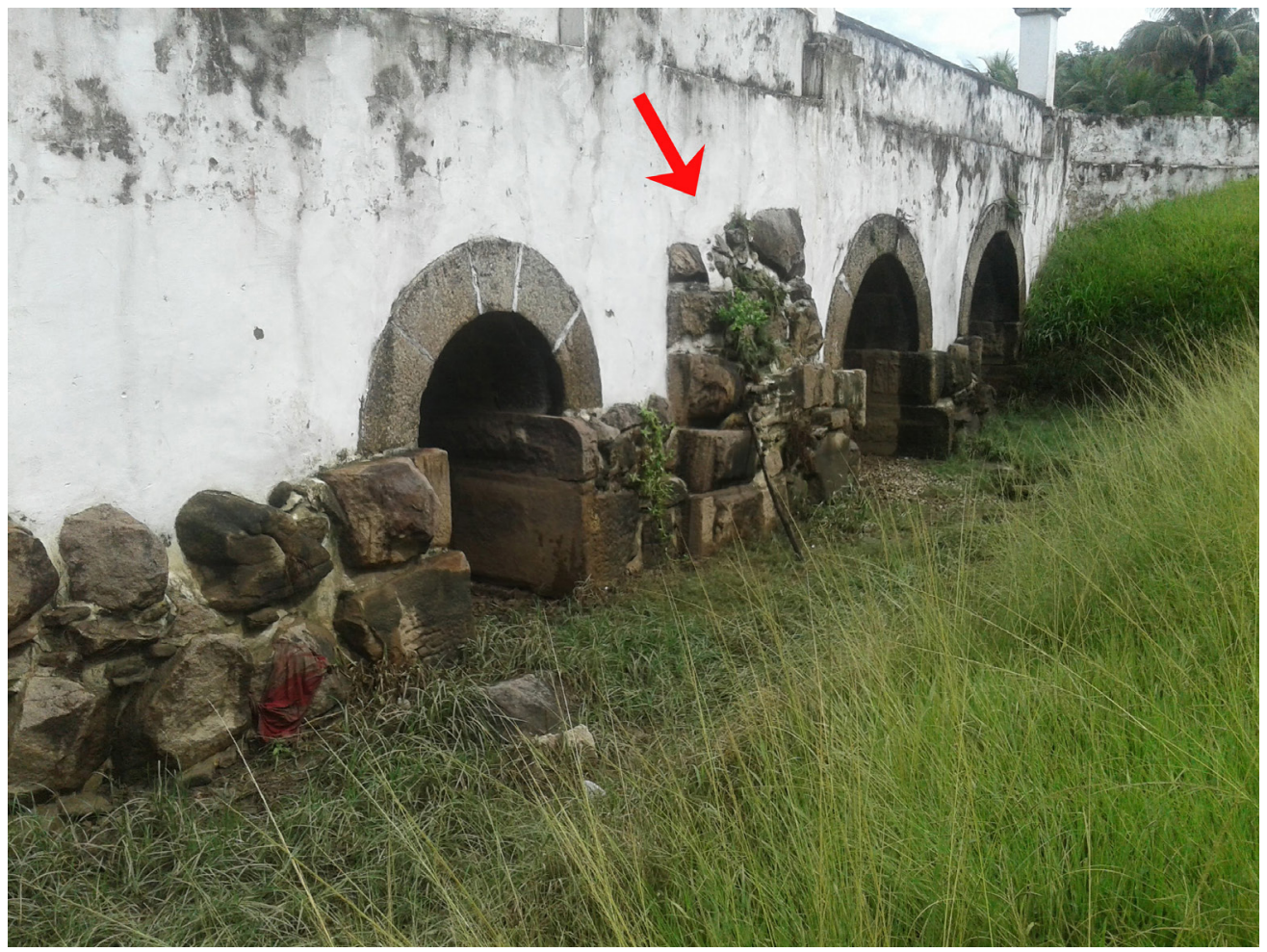

Figura 6 - Ruínas de antiga mísula, 2018 . Fotografia da autora.

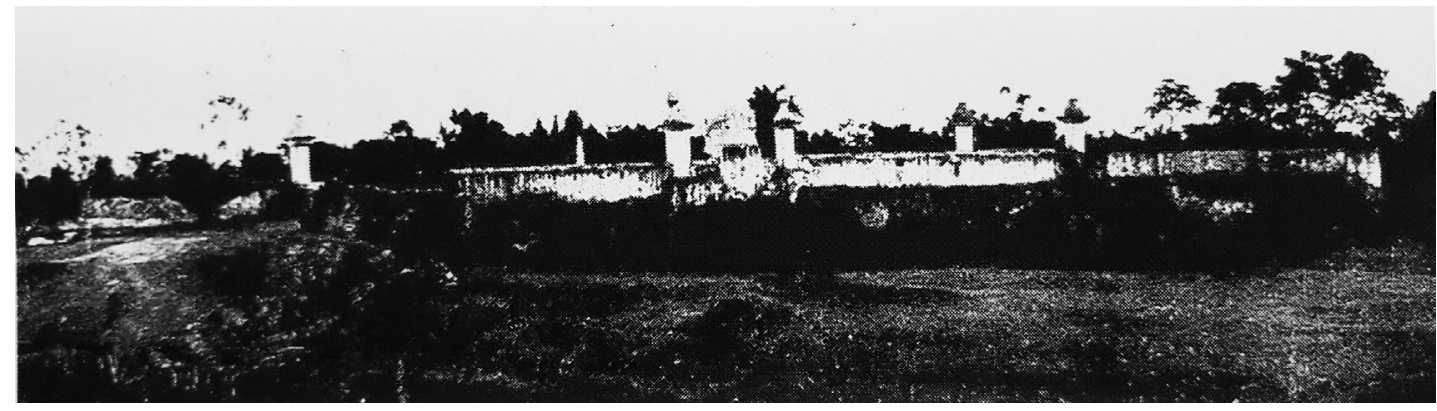

Fotografias em ângulo semelhante, publicadas pelo jornal $\bigcirc$ Globo, em 1927, ${ }^{53}$ e por Ferreira, ${ }^{54}$ em 1929, também exibem pinhas arredondas (Figuras 10 e 111 . Freitas ${ }^{55}$ afirma que, no passado, as pinhas que ornavam as pilastras eram de louça do Porto, sendo possível que as pinhas ilustradas por Niemeyer correspondam a tais peças.

A variação nas condições de integridade das colunas entre 1848 e os dias atuais é ilustrada esquematicamente na Figura 12, tendo como base imagens publicadas por Niemeyer, ${ }^{56}$ Ferreira, ${ }^{57}$ Revista da Semana, ${ }^{58}$ Corrêa, ${ }^{59}$ 

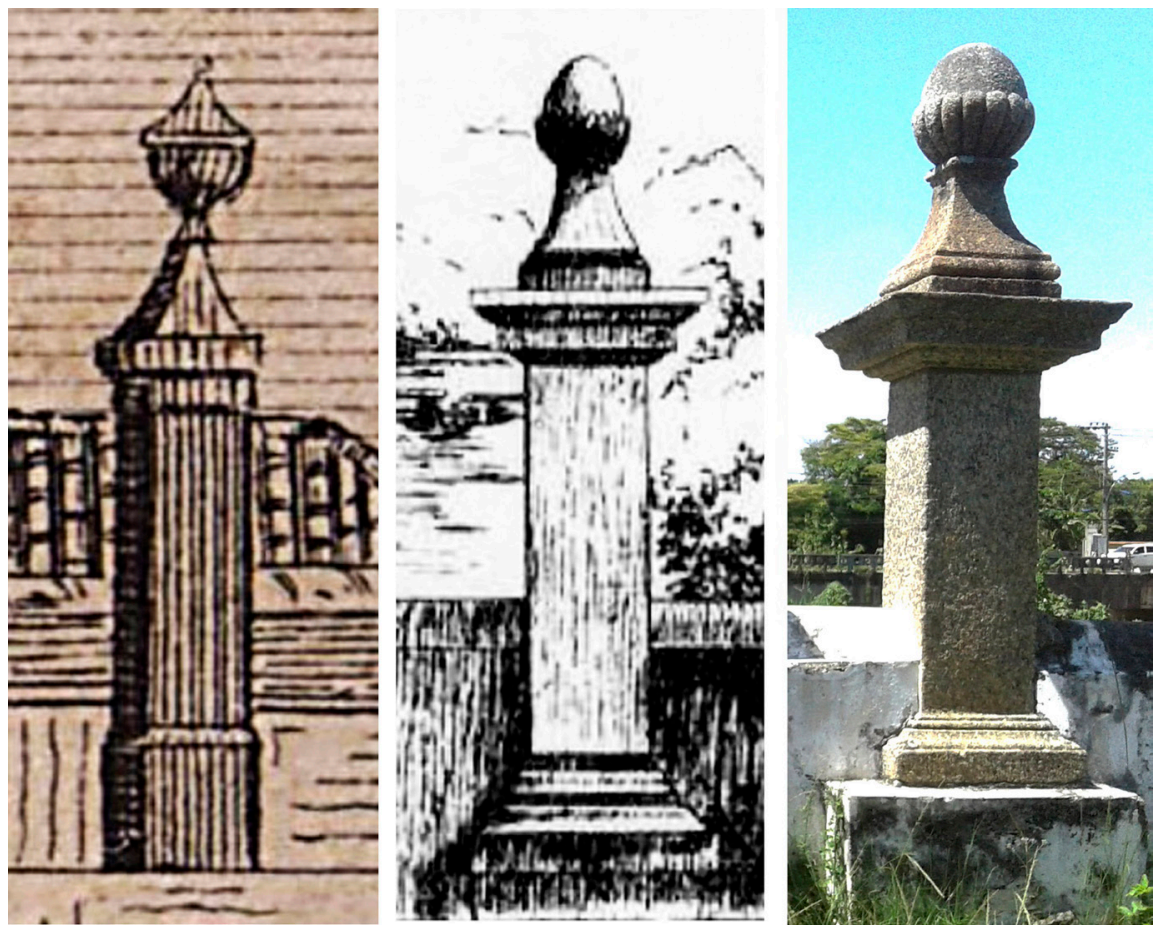

Figura 8 - Colunas como retratadas por Niemeyer (1848), à esquerda; por Corrêa (1939), no centro; e forma atual (2018), à direita. Fotografia da autora.

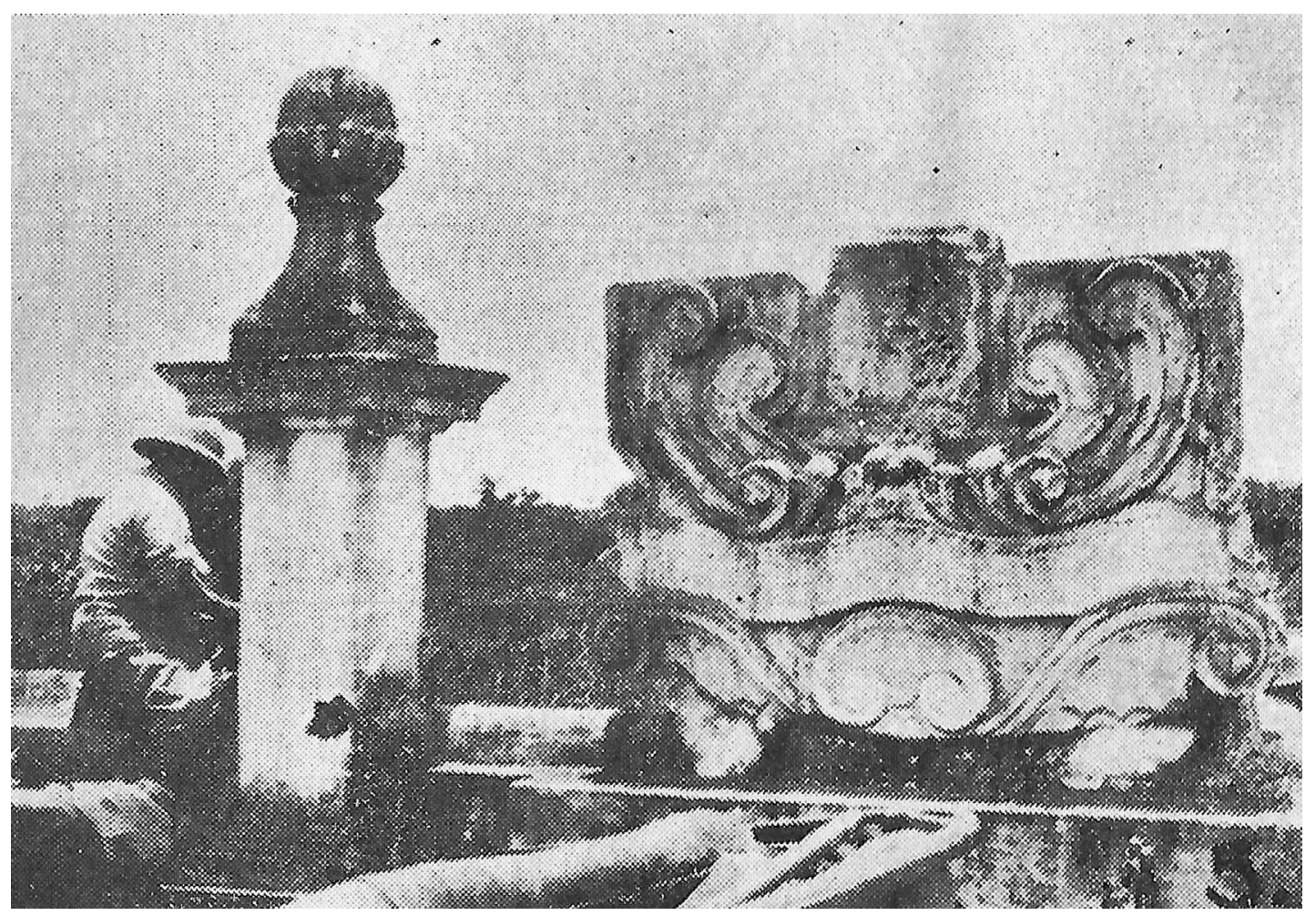

Figura 9 - Fotografia do dístico em 1925, por Américo Netto. Fonte: Netto (1927). 
60. Será (1963); A Ponte (1967); A Ponte (1971); Ponte (2007).

61. Mansur; Morais (2014)
O Globo ${ }^{60}$ e Ronaldo Morais. ${ }^{61}$ Constata-se que, a partir de 1929, das colunas ora existentes, apenas três mantiveram os fustes íntegros: duas laterais ao dístico e uma à esquerda da entrada sul. Todas as pinhas, sem exceção, foram removidas em algum momento.

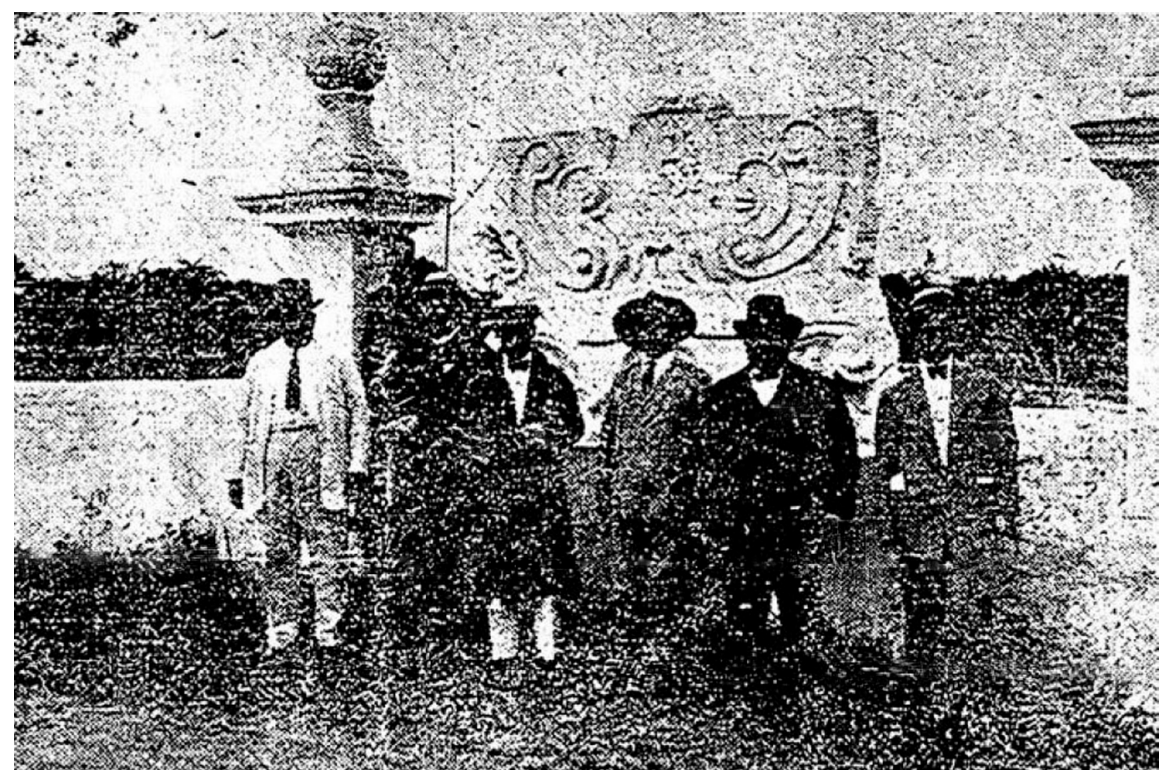

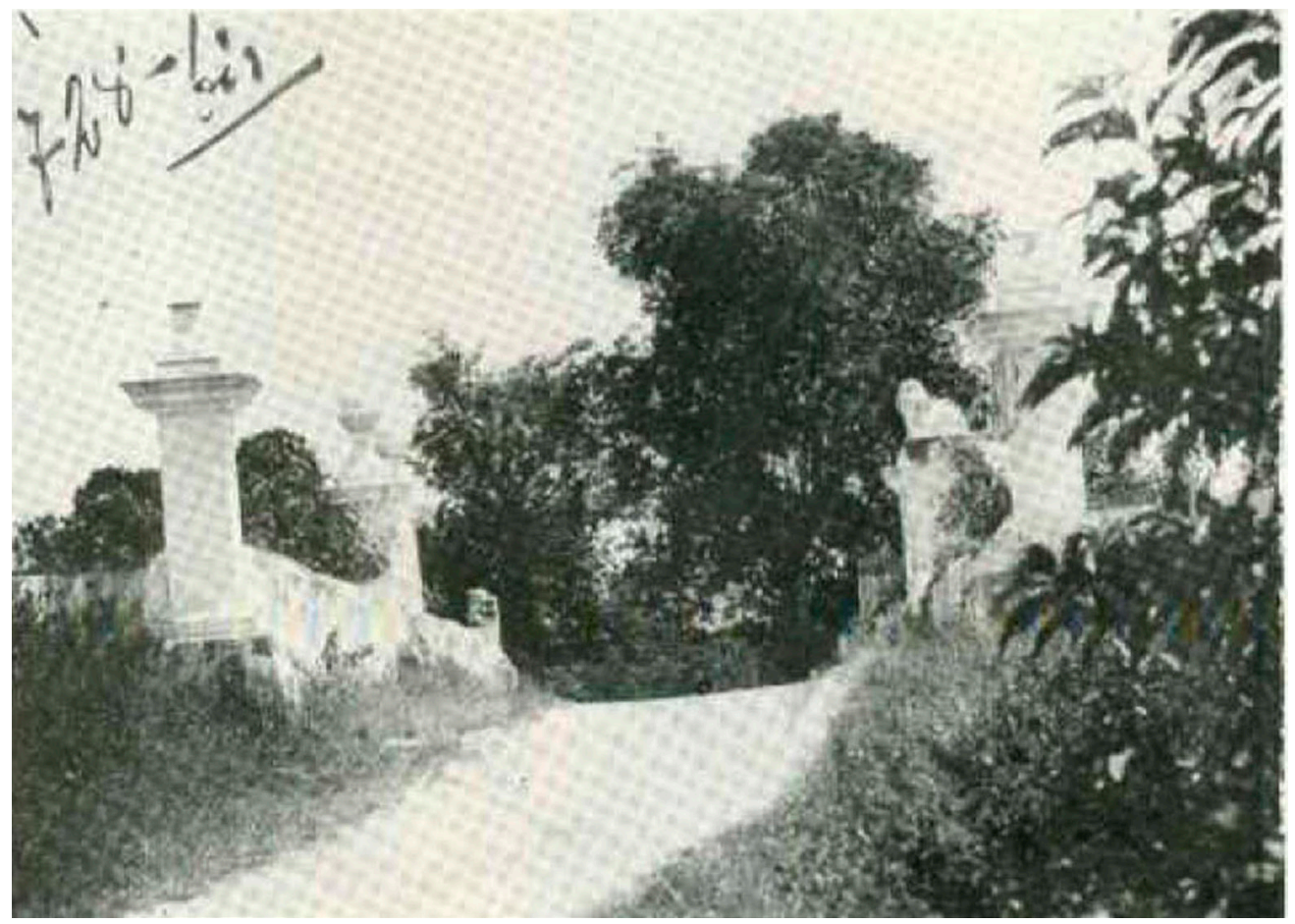

Figura 11 - Vista da entrada sul da Ponte dos Jesuítas. Fonte: Ferreira (1929). 
Além de apresentar diferenças na forma e no número de colunas, o dístico decorativo retratado por Niemeyer é também distinto do atual. Na imagem do engenheiro, esse é formado por quatro blocos cujos limites são indicados por linhas de junção (Figuras 13a,b). No topo, há um emblema e uma coroa que guardam semelhança com o Brasão Imperial do Brasil (Figura 13c). No centro, está o brasão jesuítico, gravado em bloco hexagonal com as iniciais $\| \mathrm{HS}$ e a data. $\bigcirc$ topo do brasão está encravado em uma cantaria com espirais decorativas. Na base do conjunto, há outra cantaria com espirais. Nota-se, contudo, que o desenho das aspirais difere do atual.

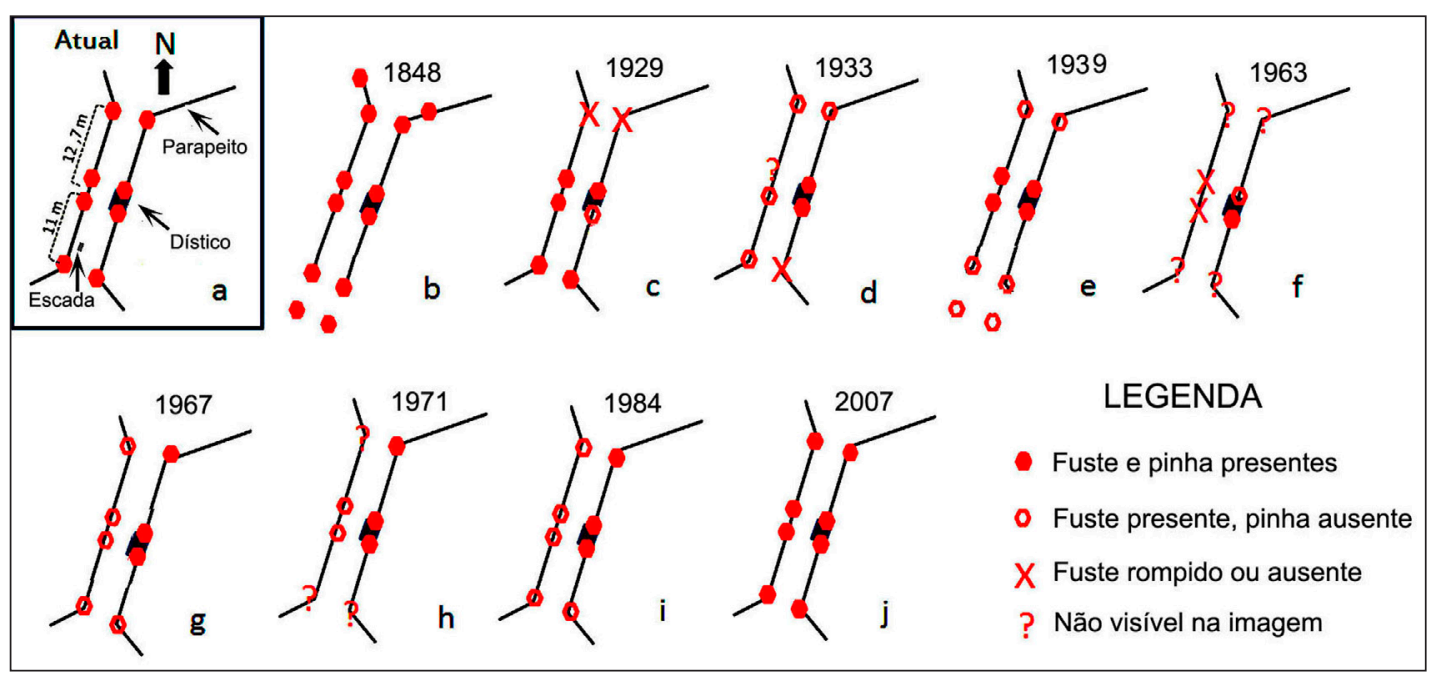

Figura 12 - Diagrama esquemático ilustrando situação física de fustes e pinhas entre 1848 e 2007. No topo, à esquerda, configuração atual.
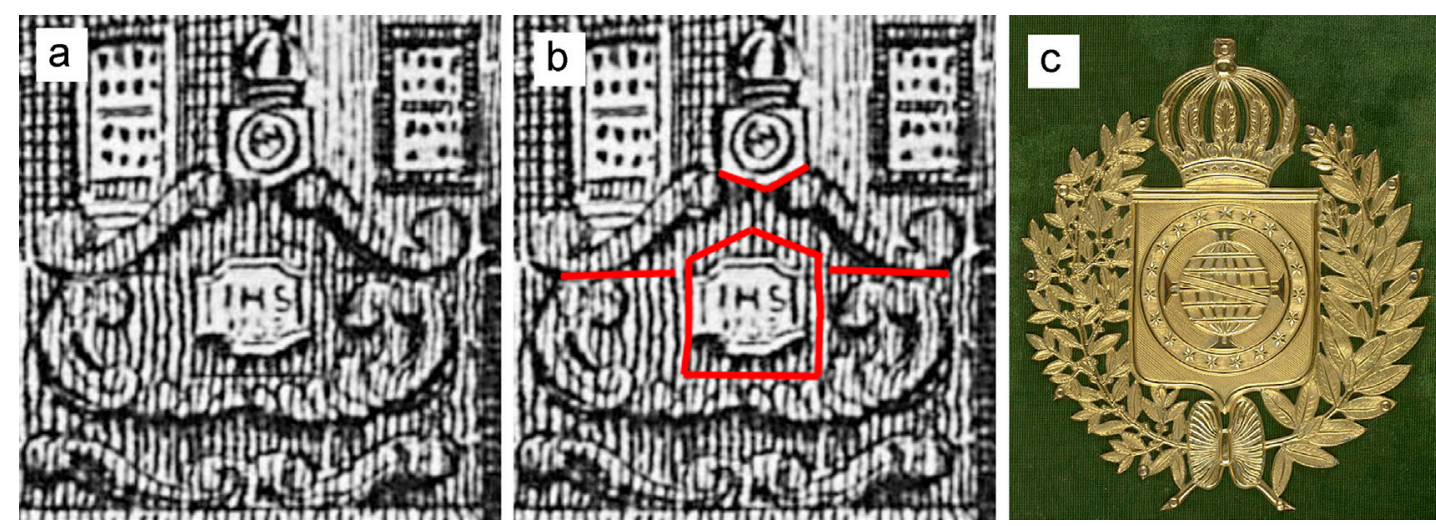

Figura 13 - (a) Detalhe do dístico segundo ilustração de Niemeyer (1848); (b) destaque das linhas de junção entre cantarias; (c). Brasão Imperial na capa da Constituição do Império do Brasil. Acervo do Arquivo Nacional. 
62. Cf. Goes (1942).

63. Mansur; Morais (2014)
As colunas que ladeiam o dístico na imagem de 1848 exibem entre si o mesmo espaçamento das colunas atuais, mas apresentam diferentes distâncias em relação ao dístico, como pode ser observado nas linhas que ilustram relações de proporção (Figura 14), revelando que o conjunto anterior apresentava maiores dimensões.
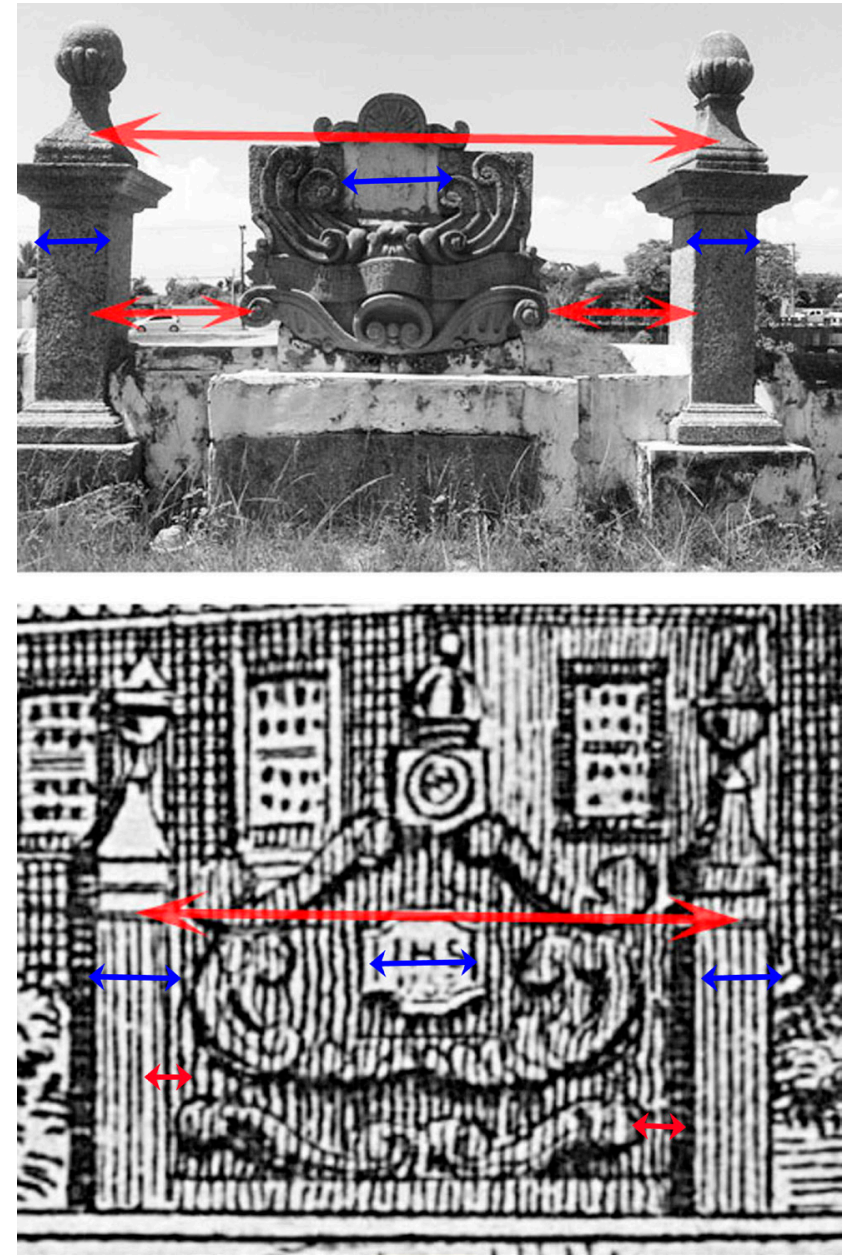

A Figura 15 reúne imagens do dístico entre o século XIX e os dias ałuais. Observa-se que, a partir dos anos 1930, o brasão passa a exibir como arremate uma cantaria onde figura uma representação do sol ladeada por espirais. Vê-se, em imagem de 1931 publicada em $O$ Globo, que nessa data a peça se encontrava danificada, pois a espiral direita está ausente (Figura 15e). Posteriormente, a peça é vista em $1942 \mathrm{com}$ as duas espirais completas ${ }^{62}$ (Figuras 15g), desaparecendo por completo em fotografia de Ronaldo Morais ${ }^{63}$ datada de 1984 e ressurgindo nas imagens a partir de 1991. A fita com a frase latina, rompida em sua 
extremidade direita nas fotografias entre 1925 e 1935, reaparece restaurada em imagens posteriores. Freitas ${ }^{64}$ apresenta duas reproduções do dístico elaboradas por Noronha Paiva à época do bicentenário da ponte, nos anos 1950. Em uma delas, a extremidade da fita está rompida e, em outra, restaurada. Acredita-se, portanto, que tal restauração tenha ocorrido nesse período. Na terceira imagem, enfeites em forma de espirais são vistos na junção das colunas centrais com a mureta. Tais adereços não são observados em nenhuma das demais imagens analisadas nem na construção atual.

No conjunto de representações do dístico, apenas o brasão jesuítico manteve suas caraterísticas desde o século XIX. Apesar da corrosão da borda hexagonal e das gravações em alto-relevo, o brasão atual pode ser identificado como o retratado por Niemeyer em 1848. O efeito da erosão sobre a rocha em período mais recente pode ser avaliado ao comparar-se a imagem de $1929 \mathrm{com}$ uma imagem atual (Figura 16).

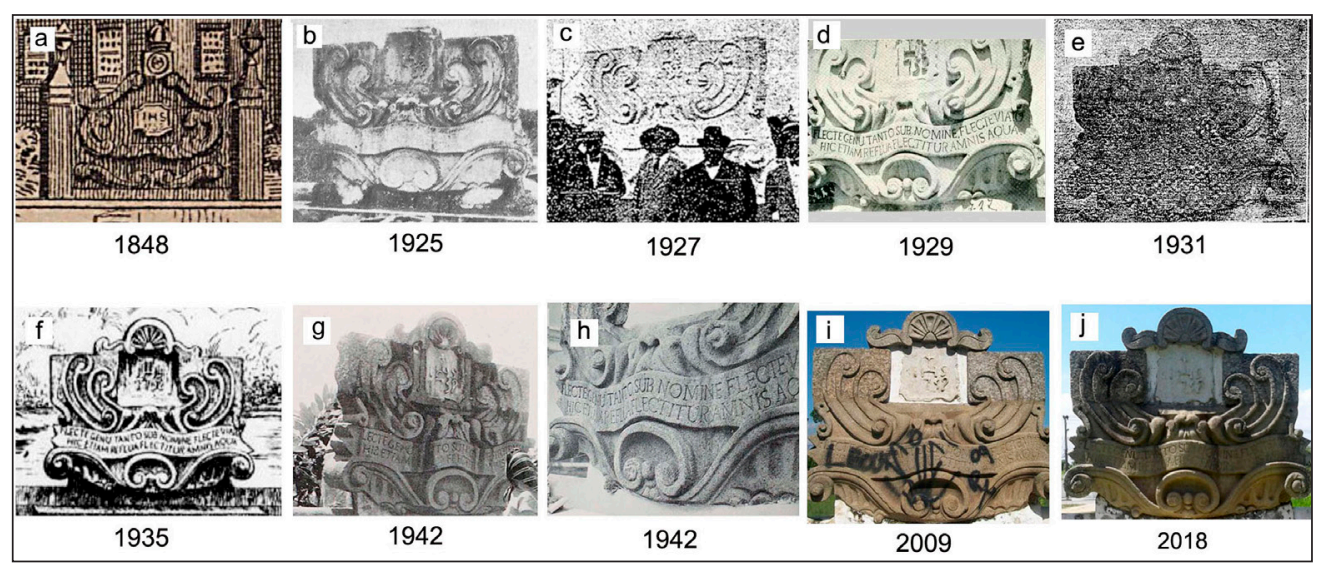

Figura 15 - Imagens do dístico entre 1848 e 2018 : (a) Niemeyer (1848), (b) Netto (1927), (c) $\bigcirc$ Resgate (1927), (d) Ferreira (1929), (e) $\bigcirc$ Modernismo (1931), (f) Corrêa (1939), (g, h) Goes (1942), (i, i) Fotografia da autora (2018).
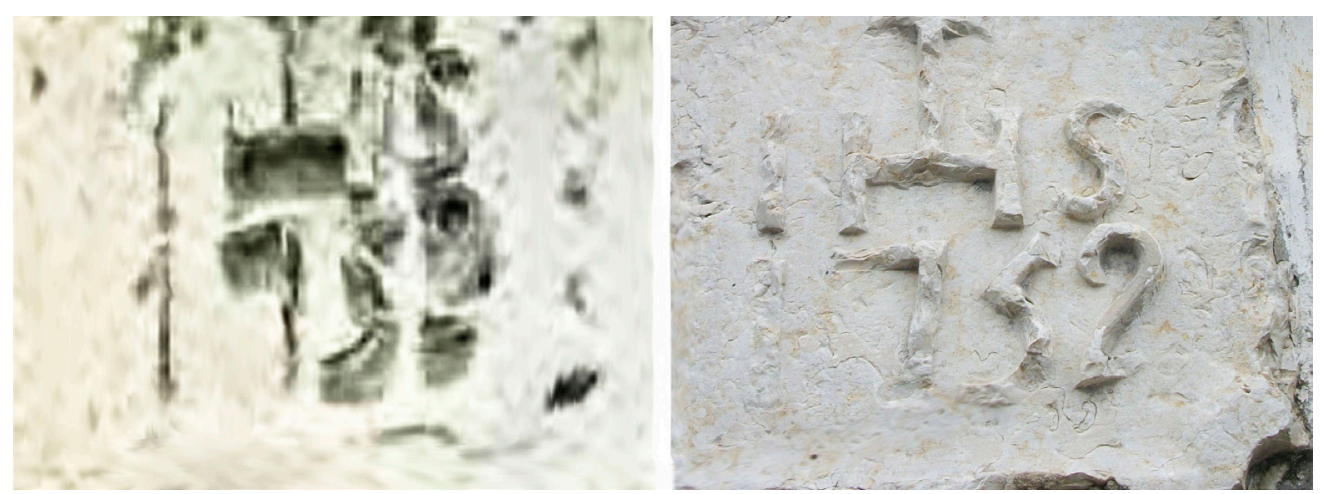

Figura 16 - Detalhe do brasão jesuítico em Ferreira (1929) e em fotografia da autora (2018). 
65. Bastos (1940).

66. Cf. Morais Filho (18--?). Alexandre José de Melo Moraes Filho morreu em 1919. Silvio Romero, que prefaciou o texto de Moraes Filho, morreu em 1914.

67. Cf. Freitas (1985a).

68. Cf. Almeida (2015).

69. Cf. Faria; Almeida (2016).

\section{AS ROCHAS UTILIZADAS NA CONSTRUÇÃO}

Desde o início da ocupação de Santa Cruz, os jesuítas usaram rochas como material de construção. Bastos ${ }^{65}$ denomina "monstro de pedra" a antiga sede, cuja origem remonta a 1707. Os religiosos, que eram versados na arte da extração de rochas, produziam as ferramentas na própria fazenda. Entre os itens inventariados nos livros de registros de 1768, constavam escodas e sutas para uso dos canteiros, pedreiros e cavouqueiros. ${ }^{66}$ Hábeis canteiros, os padres faziam extração a frio, ou seja, sem uso de explosivos. ${ }^{67}$

Três grandes pedreiras funcionaram no entorno da sede da Fazenda Santa Cruz (Figura 17), todas situadas às margens da estrada que fazia a ligação entre a casa central e a Ponte dos Jesuítas. A pedreira mais próxima, situada um quilômetro ao sul da sede, no hoje conhecido Morro do Cruzeiro, manteve-se ativa por quase duzentos anos. ${ }^{68}$ Suas rochas foram utilizadas na construção do monastério no início do século XVIII e do Matadouro Imperial de Santa Cruz ao final do século XIX.69 A segunda pedreira situava-se na Serra da Paciência, quatro quilômetros a leste do monastério. Ambas estavam a uma distância de aproximadamente cinco quilômetros do local onde foi erguida a Ponte dos Jesuítas. A terceira pedreira, do Morro do Itá (itá = pedra), se encontrava a dois quilômetros do local de construção da ponte, onde hoje está o Parque Municipal Cidade da Criança, no entroncamento da estrada Rio-Santos com a avenida Brasil. Essa antiga pedreira, hoje desativada, apresenta várias feições que evidenciam processos de extração a frio.

A Serra da Paciência e o Morro do Cruzeiro são formados por ortognaisses com diferentes graus de deformação, variando de litotipos com texturas ígneas preservadas a gnaisses miloníticos. A variação do grau de deformação resulta em tipos texturalmente distintos (Figura 18). A rocha predominante é um granada-biotita gnaisse com porfiroclastos centimétricos de microclina. Megacristais de feldspato chegam a ultrapassar quatro centímetros, e a granada se destaca como grão arredondado, vermelho escuro, de poucos milímetros a dois centímetros. Os tipos com textura ígnea preservada possuem feldspatos tabulares. O Morro do Itá, por sua vez, é formado por allanita granito equigranular de grão fino, estruturalmente isotrópico, de coloração cinza-clara passando a rosa - um rosa-amarelado, em razão do aumento do grau intempérico (Figura 19). Allanita prismática, de cor negra, exibe halos avermelhados, resultantes da emissão de partículas radioativas sobre feldspatos adjacentes. Tal rocha tem sua origem como diques tabulares com poucos metros 
de largura, sendo conhecida, no Rio de Janeiro, como "Granito Favela", em razão da frequência com que ocorre no topo dos morros cariocas. ${ }^{70} \mathrm{Nas}$ pesquisas de campo realizadas nesse trabalho, allanita granito foi a única rocha encontrada aflorando na antiga pedreira do Morro do Itá, onde gnaisses ocorrem apenas como enclaves de poucos centímetros, tendo também sido encontrado junto à pedreira um bloco isolado de granada-biotita gnaisse porfiroclástico com granada (Figura 20).

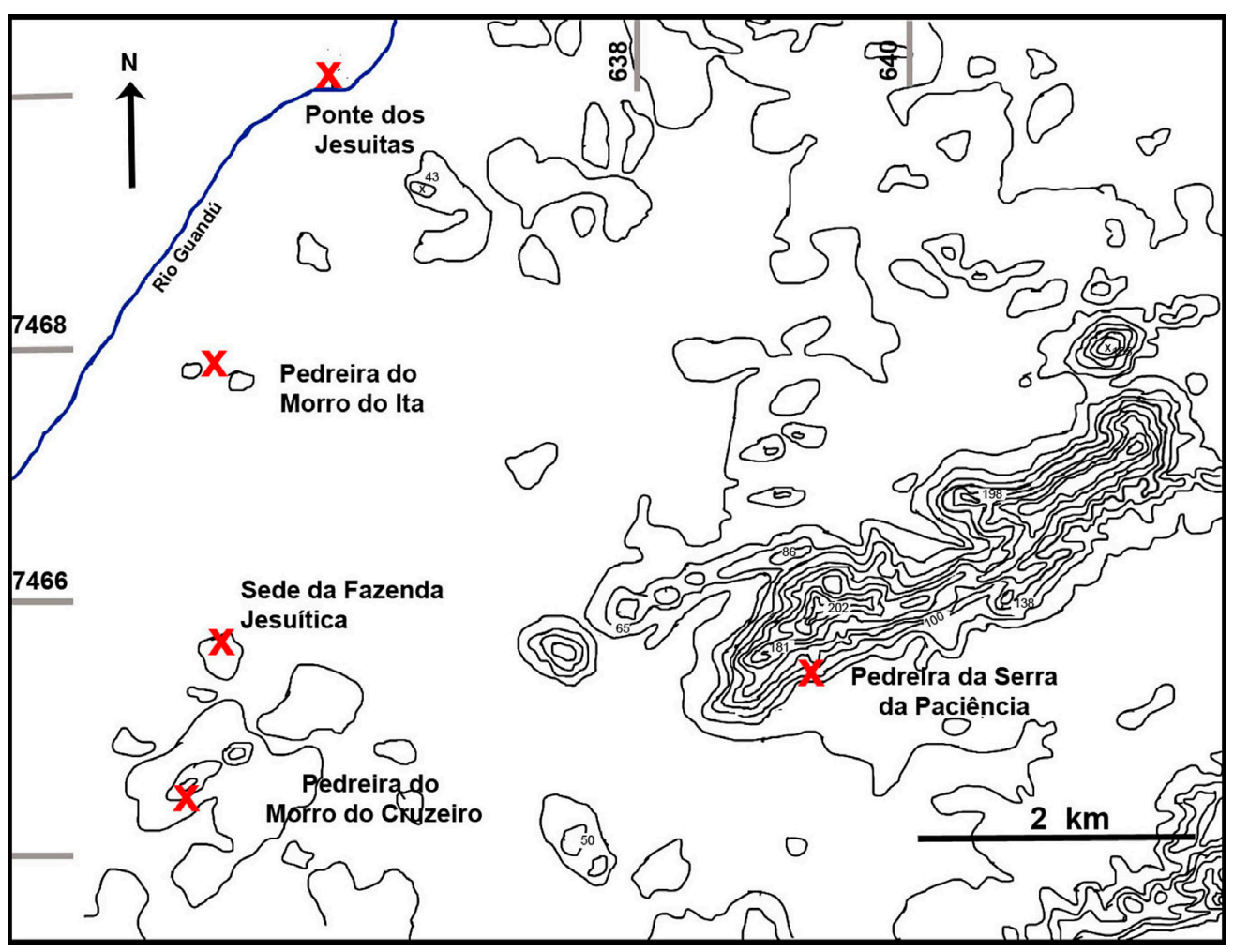

Figura 17 - Localização das antigas pedreiras da região de Santa Cruz, da sede da fazenda e da Ponte dos Jesuítas. Intervalo de curvas de nível em 20 m. Base topográfica: Ministério do Exército (1987).

As dificuldades que envolvem o transporte de rochas fazem da pedreira do Morro do ltá a mais provável fonte de matéria-prima para a construção da Ponte dos Jesuítas. Contudo, o estudo petrográfico revelou o uso não apenas de granito, mas também de gnaisses equivalentes aos aflorantes no Morro do Cruzeiro e na Serra da Paciência, na composição de cantarias que revestem paredes laterais e arcos (Figura 21 a, b, c, d), enquanto blocos da mesoestrutura são, predominantemente, de allanita granito (Figura 21 e, f). $\bigcirc$ gnaisse predominante nas cantarias exibe foliação anastomosada ao redor de porfiroclastos de microclina e de granada, mas, assim como no Morro do Cruzeiro e nas paredes do Matadouro
70. Cf. Pires; Valença; Ribeiro (1982) 
Imperial, há tipos com feldspatos centimétricos com hábito tabular, representativos de porções menos deformadas do protólito ígneo.
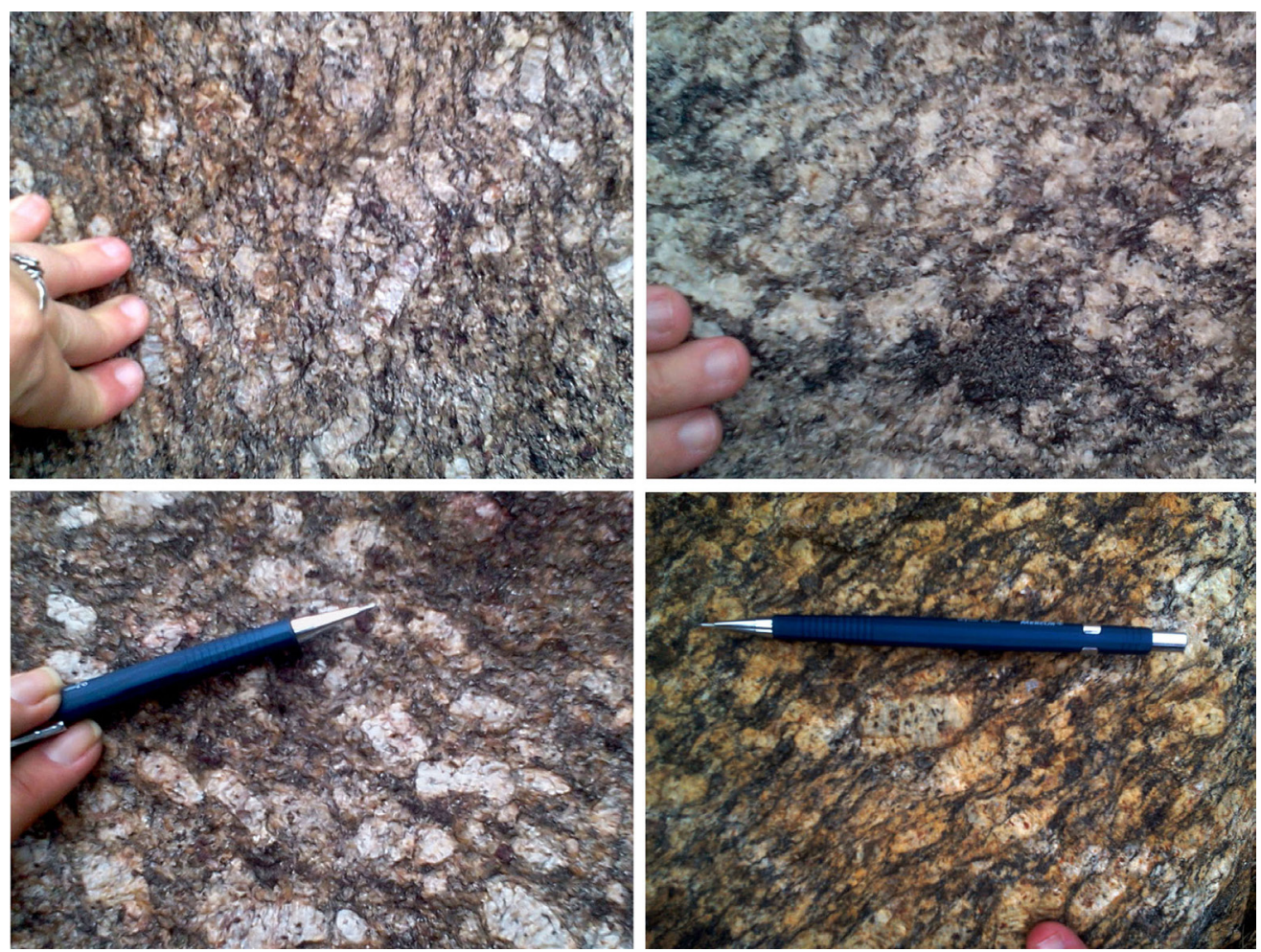

Figura 18 - Variações texturais resultantes do grau de deformação e da direção de corte em granada-biotita gnaisse do Morro do Cruzeiro, Santa Cruz. Fotografia da autora (2015).
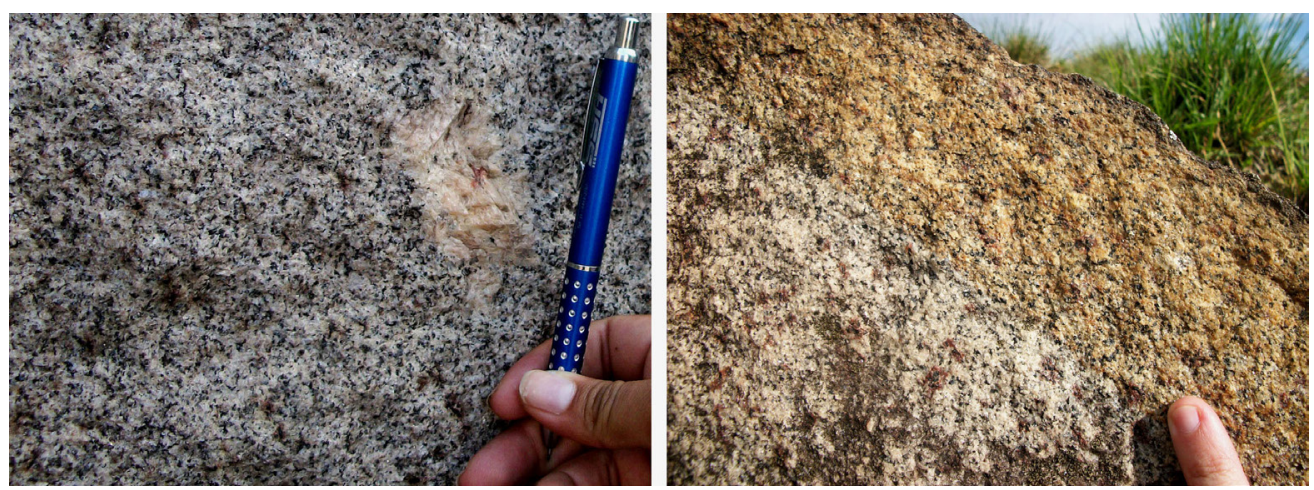

Figura 19 - Variações de cor devido ao intemperismo no allanita granito do Morro do Itá, Santa Cruz. Fotografia da autora (2016).

A correspondência entre rochas sugere, a princípio, ter sido o Morro do Cruzeiro a fonte de matéria-prima para as cantarias gnáissicas. $\bigcirc$ uso de rochas de uma pedreira mais distante que a do Morro do Ita poderia ser justificado pela 
maior facilidade de extração do gnaisse foliado em contraponto ao granito, de mais difícil lavra. Entretanto, um mapa geológico de 1965 revela que, no passado, - Morro do lta exibia uma faixa de gnaisses com granada em uma área atualmente aplainada. ${ }^{71}$ Acredita-se, portanto, que tal rocha tenha sido totalmente extraída no decorrer da vida ativa da pedreira do Morro do lta, e que o gnaisse utilizado na ponte também seja proveniente do local.

dístico é formado por quatro tipos de rochas: (1) granito equigranular com allanita, compondo a base com a inscrição latina; (2) calcário de granulometria fina no brasão com a data e o símbolo $\mid H S$; (3) granada-biotita gnaisse porfiroclástico, compondo as cantarias laterais ao calcário; e (4) granito equigranular de granulação grossa na peça em forma de sol que arremata o conjunto (Figura 22).

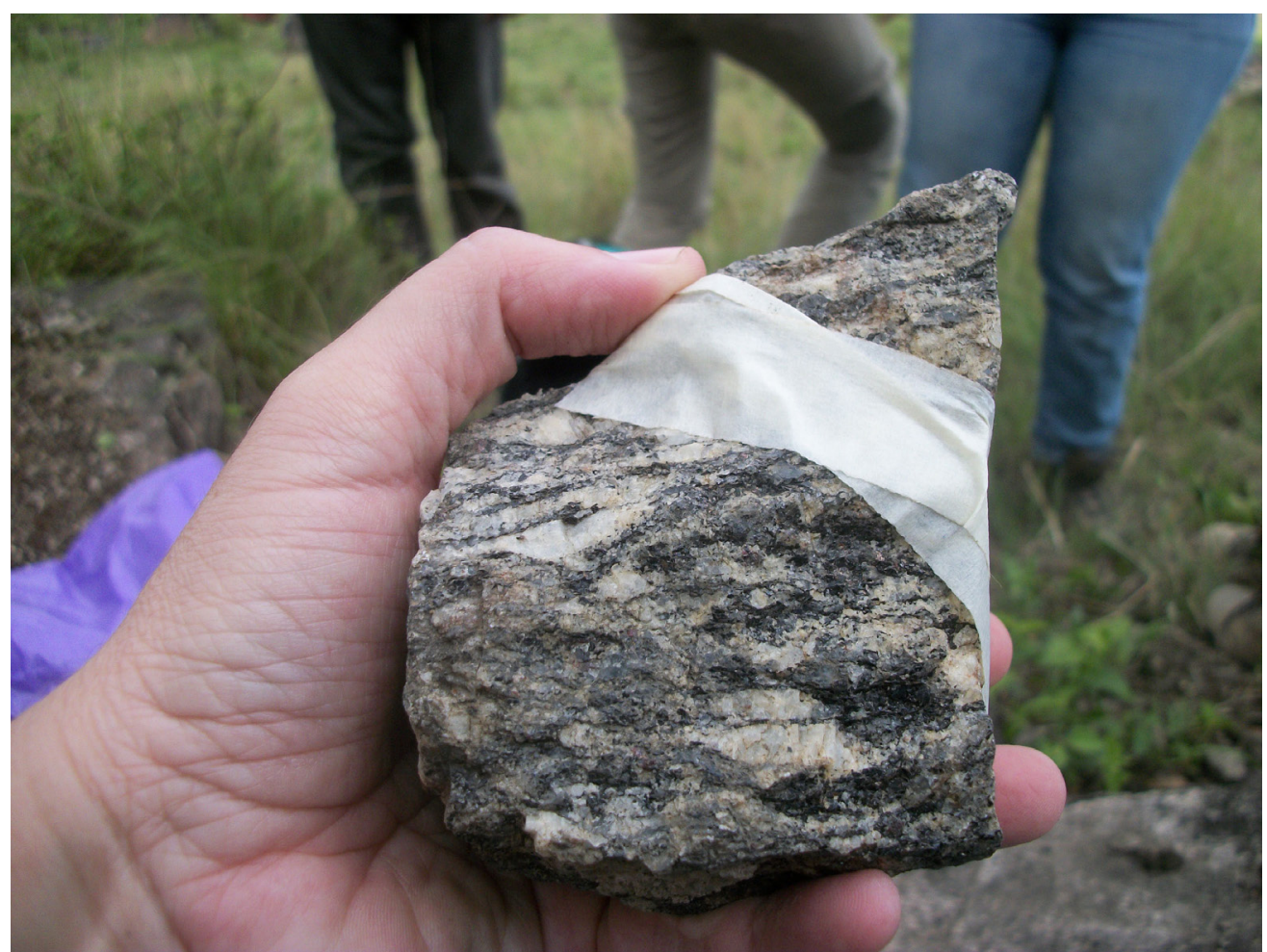

Figura 20 - Bloco de granada-biotita gnaisse do Morro do ltá, Santa Cruz. Fotografia da autora.

A base é esculpida em monobloco maciço de allanita granito, de cor rósea, com composição e textura compatível com as rochas do Morro do Ita (Figura 23). Observações na pedreira e análise de seções delgadas de suas rochas revelam que a passagem da cor cinza para rósea resulta do maior grau de alteração dos minerais ricos em ferro e dos feldspatos (Figuras 19 e 24).
71. Cf. Helmbold; Valença; Leonardo Jr. (1965). 

correlato, como seria apropriado, mas sim granada-biotita gnaisse porfiroclástico, fixado com uma camada de cimento cujo agregado, de granulação grossa, contém grãos de quartzo, feldspato e biotita (Figura 25).

Figura 21 - Cantarias da mesoestrutura da Ponte dos Jesuítas: (a) granada-biotita gnaisse com feldspatos idiomórficos preservados; (b) granada-biotita gnaisse em corte de rocha paralelo à foliação; (c) granada-biotita gnaisse em corte perpendicular à foliação e paralelo ao eixo de estiramento; (d) granada-biotita gnaisse em corte perpendicular ao eixo de estiramento e à foliação; (e) allanita granito em bloco da mesoestrutura; (f) allanita granito em cantaria de revestimento de túnel. Fotografia da autora (2018).
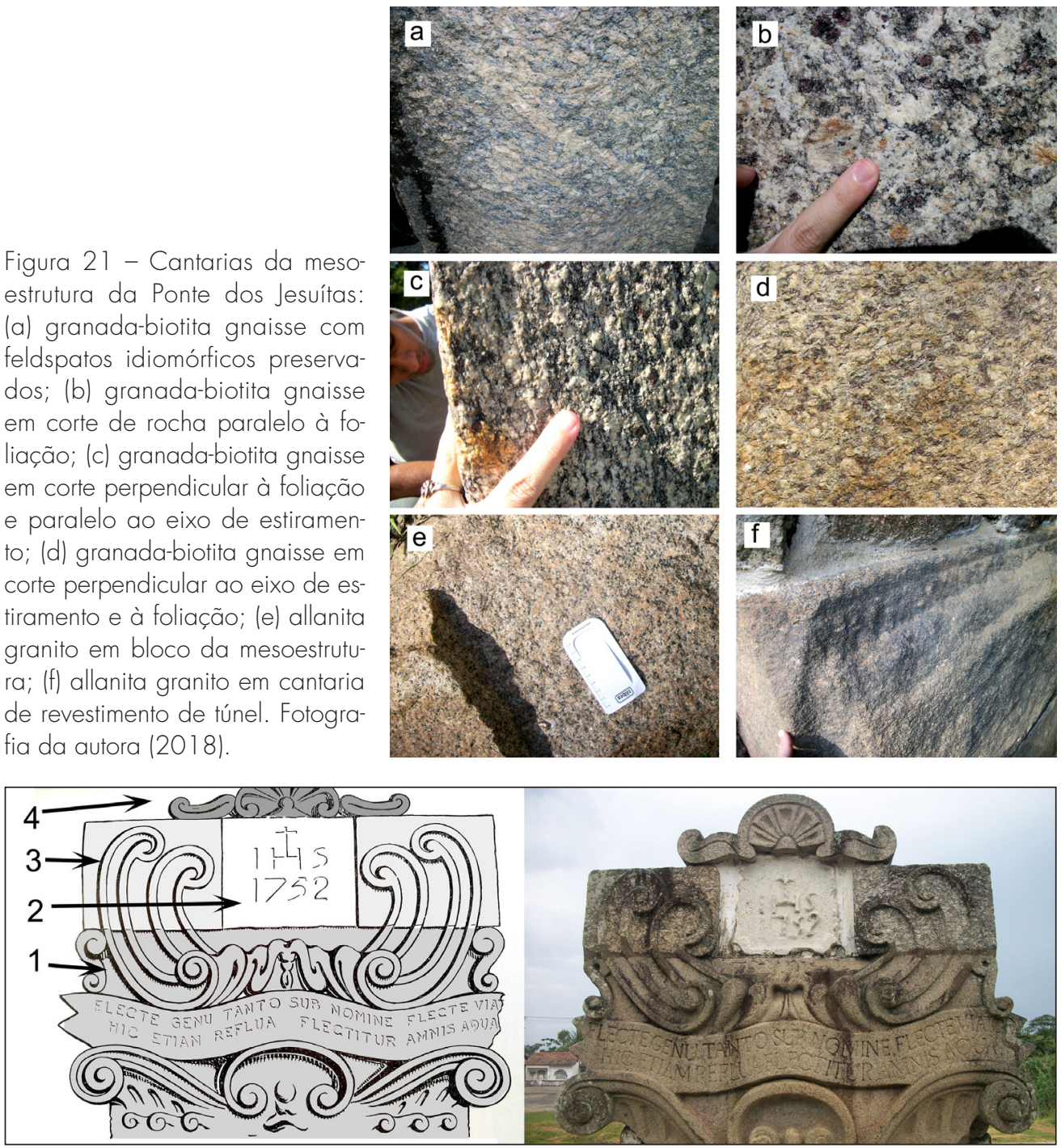

Figura 22 - Rochas que compõem o dístico da Ponte dos Jesuítas: (1) allanita granito; (2) calcário; (3) granada-biotita gnaisse; (4) granito equigranular de granulação grossa. Fotografia da autora (2018).

Freitas $^{72}$ presume, equivocadamente, que a extremidade da fita não teria sido rompida, mas erodida, por ser o bloco composto em "pedra de Lioz". $\bigcirc$ termo "lioz" é aplicado a um tipo de calcário que ocorre nos arredores de Lisboa e do qual foram trazidos vários exemplares no período colonial. Contudo, muitos monumentos no Brasil tidos como de pedra lioz são compostos na 


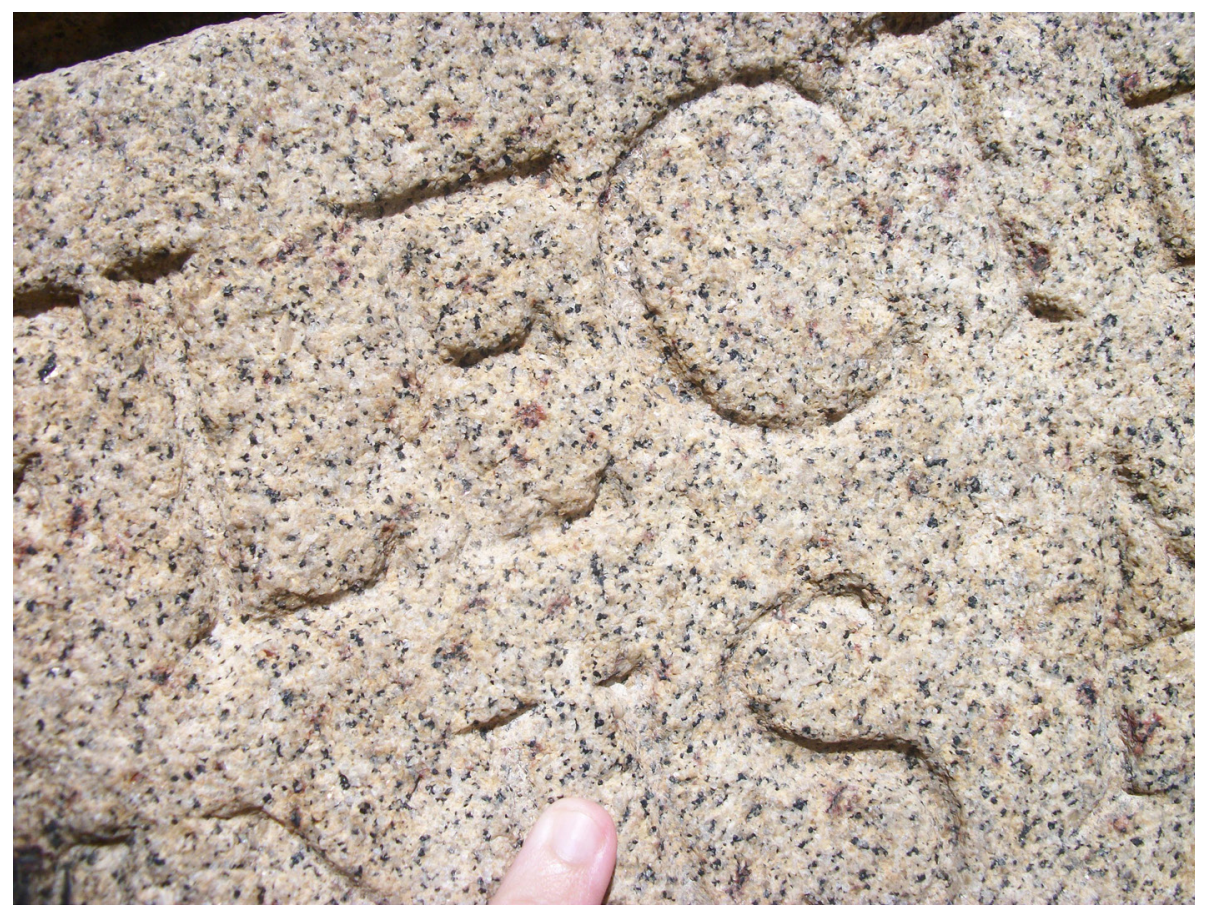

Figura 23 - Detalhe da inscrição latina em baixo-relevo em allanita granito. Fotografia da autora (2018).

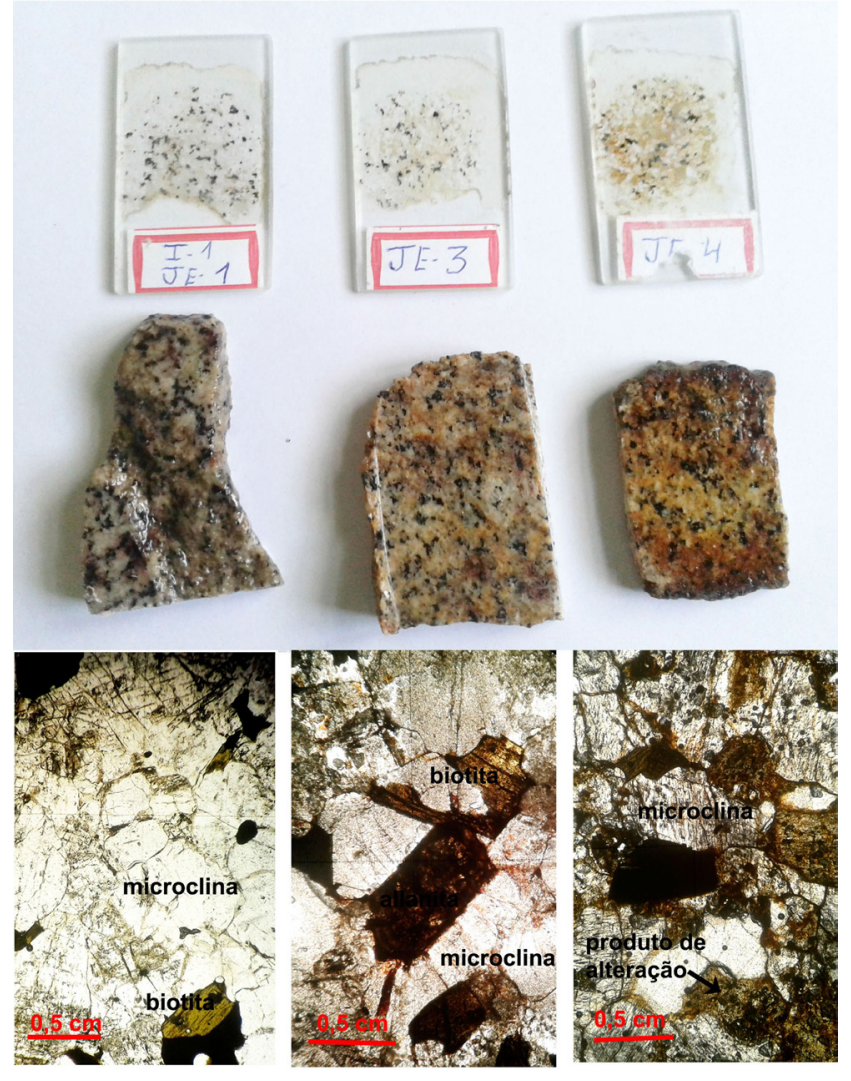

Figura 24 - No topo, lâminas de allanita granito com diferentes graus de alteração. No centro, respectivas amostras. Na base, mesmas amostras vistas por meio de microscópio petrográfico, com polarizadores paralelos. O grau de alteração é crescente da esquerda para a direita. Fotografia da autora (2018). 
realidade por rochas nacionais, como é o caso da base granítica do dístico. A única rocha com composição equivalente à da pedra lioz na Ponte dos Jesuítas é o bloco que contém o símbolo da Companhia de Jesus. Trata-se de uma rocha carbonática branca com manchas amareladas e superfície fosca, em que é possível reconhecer somatofósseis (Figura 26).

Figura $25-\mathrm{Ci}-$ mento com agregado de granulação grossa unindo cantarias de allanita granito e granada-biotita gnaisse. Fotografia da autora (2018).

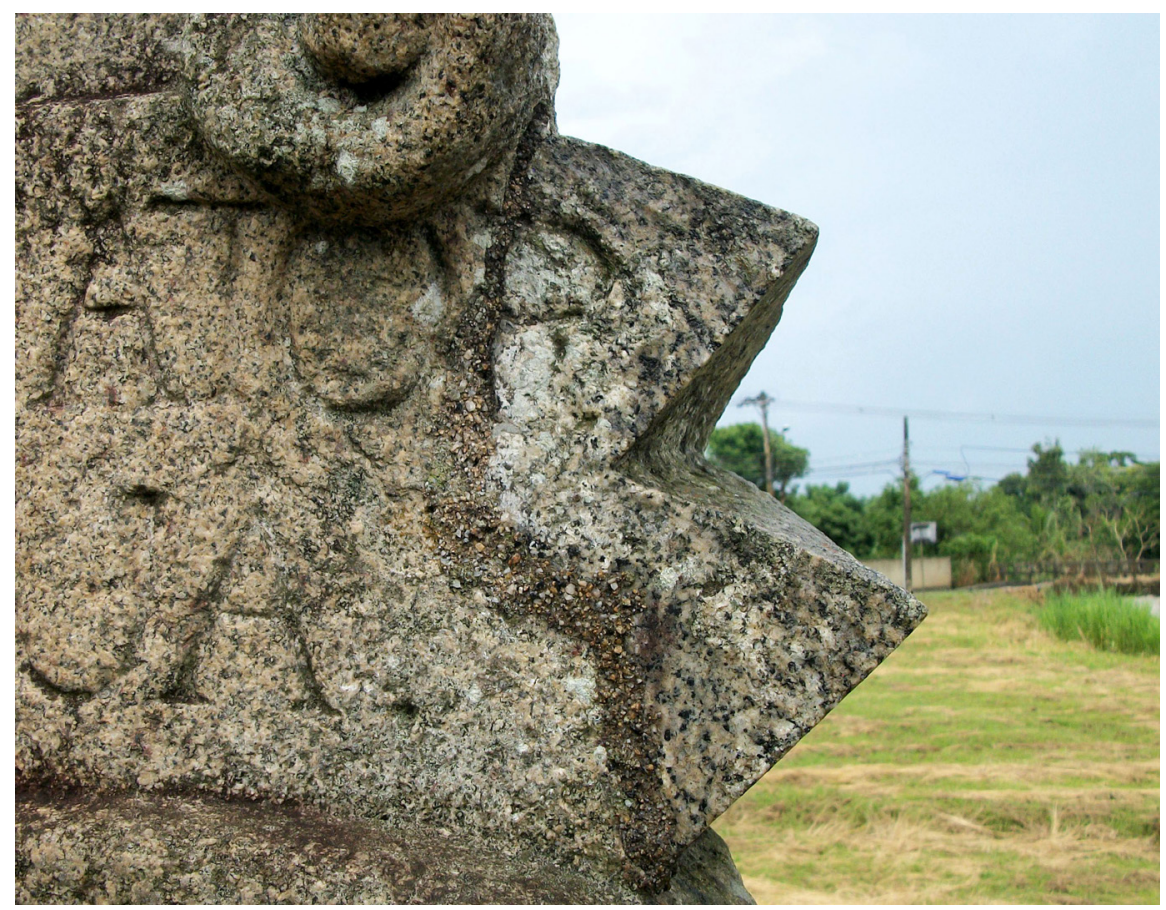

Figura $26-$ Somatofósseis compatíveis com pedra lioz da cantaria do brasão jesuítico. Fotografia da autora (2018).

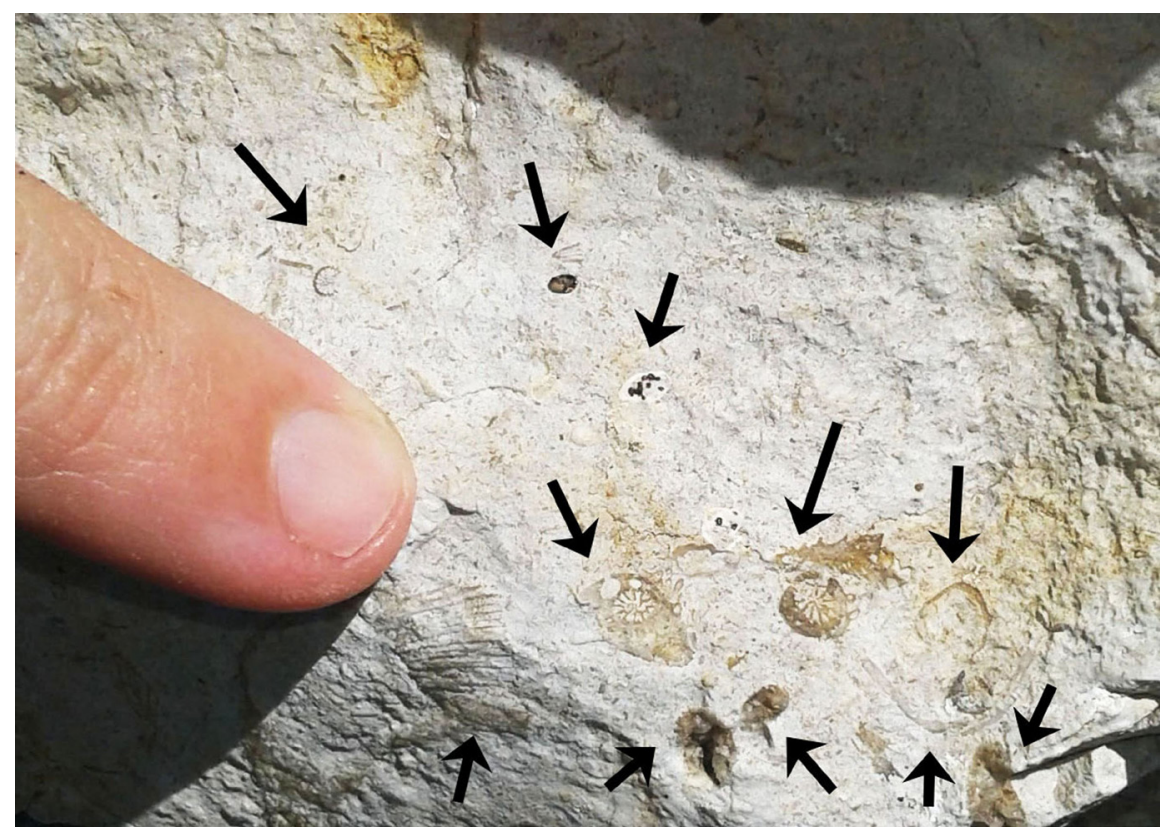


As características atuais do bloco de calcário indicam ser esse o mesmo representado por Niemeyer, ${ }^{73}$ o que o torna o único elemento do dístico retratado com a mesma aparência desde o século XIX. Ainda é possível reconhecer a moldura hexagonal trabalhada em alto-relevo, mas a peça encontra-se intensamente erodida e com diversas fissuras. Diferente do granito, rochas carbonáticas como a pedra lioz são extremamente sensíveis à ação intempérica, e sua dissolução é intensificada pela poluição atmosférica. ${ }^{74}$ Como pode ser observado na Figura 16, o número 1, anteriormente nítido no brasão, foi quase completamente removido, e o número hoje tido como 5 assemelhava-se ao 3 no início do século XX, o que explica a diversidade de interpretações quanto à data de inauguração da ponte. Porções desgastadas das letras em alto-relevo foram reconstituídas rusticamente por um material de superfície áspera e tom cinza-escuro, muito provavelmente o cimento que, segundo Freitas, ${ }^{75}$ teria sido utilizado na restauração à época do centenário (Figura 29).
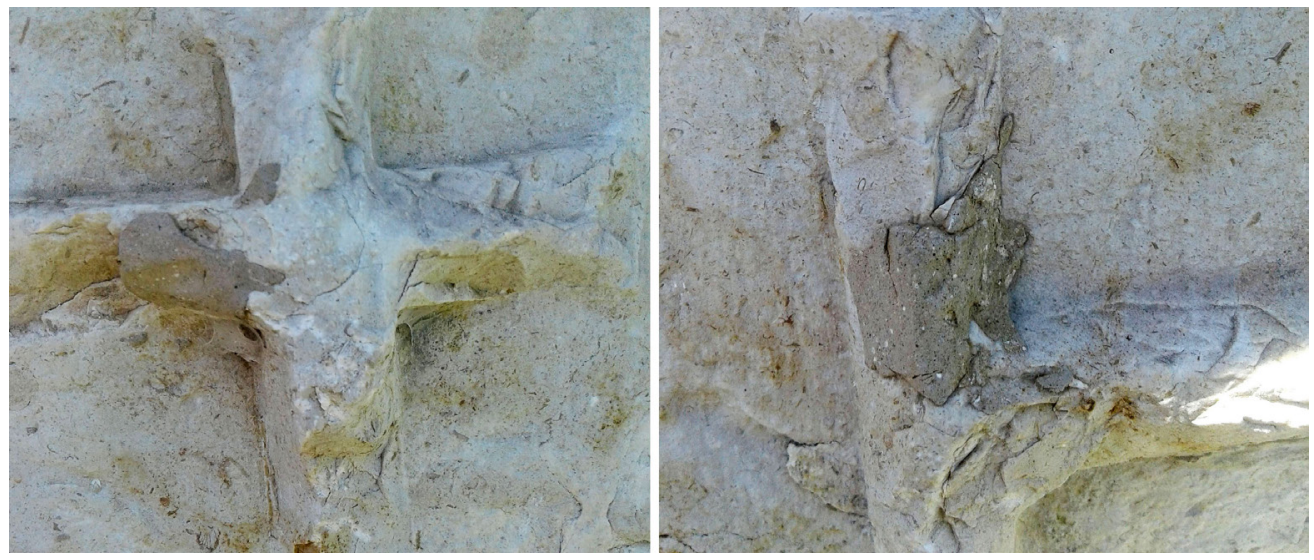

Figura 27 - Detalhe de material utilizado no restauro do brasão jesúítico. Fotografia da autora (2018).

Duas cantarias de granada-biotita gnaisse porfiroclástico ladeiam o bloco de calcário (Figura 24). Contudo, apesar de serem formadas pela mesma rocha, as cantarias gnáissicas exibem cores diferentes entre si. A situada à direita possui cor acinzentada, e a situada à esquerda, amarelo-avermelhada, o que indica maior tempo de exposição do bloco esquerdo, sugerindo períodos distintos de instalação das cantarias. Nota-se também, na peça avermelhada, um grau maior de erosão da matriz ao redor dos porfiroclastos, o que dá à superfície um aspecto mais rugoso, favorecendo a hipótese de maior tempo de exposição. Os blocos de gnaisse também apresentam acabamentos distintos em suas faces posteriores. $\bigcirc$ da esquerda, tido como o mais antigo em função de sua coloração e grau de erosão, exibe superfície mais rústica, menos aplainada que o direito (Figura 28).
73. Niemeyer (1848).

74. Cf. Baedecker; Reddy (1993).

75. Freitas (1985a). 
76. O Modernismo (1931)

77. Cf. Goes (1942).

78. Cf. Ferreira (1929).

79. Será (1963).

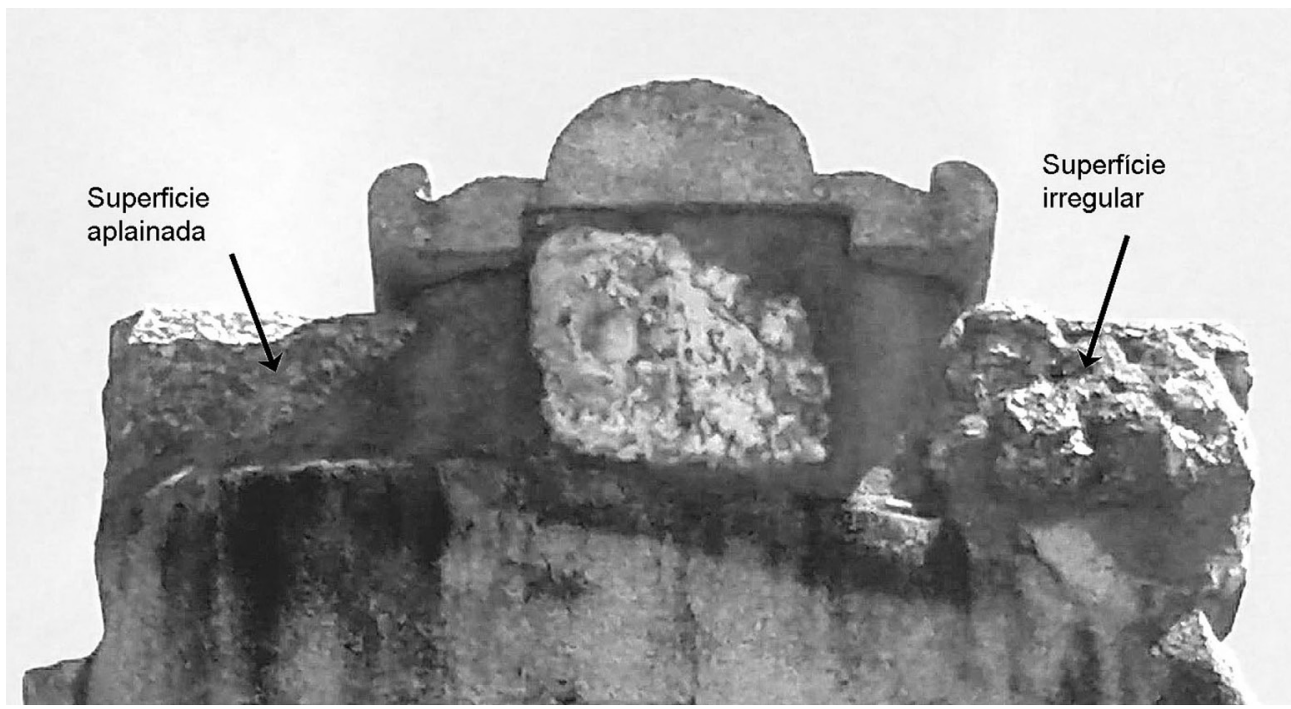

Figura 28 - Verso do dístico (observar diferença de acabamento do bloco à esquerda e à direita do calcário). Fotografia da autora (2018).

A rocha utilizada na escultura solar que arremata o brasão jesuítico é um granito cinza-rosado, equigranular, de granulação grossa, com feldspatos idiomórficos tabulares, sem correspondentes nas pedreiras de Santa Cruz. O grau de planificação de sua superfície é distinto do de superfícies rústicas, irregulares, vistas nas demais cantarias do dístico. Trata-se, portanto, de uma peça moderna, moldada em uma rocha sem conexão com a geologia local. $\bigcirc$ fato de a escultura atual ser composta em monobloco, sem emendas, permite concluir que essa não corresponde à escultura fotografada em 1931, sem a espiral direita, pelo $O$ $G$ lobo $^{76}$. Na Figura 29 é possível comparar a peça como se apresenta hoje e na imagem publicada em 1942. ${ }^{77}$

Atualmente, apenas a coluna situada no extremo norte do parapeito oeste e o par que ladeia o dístico possuem todos os elementos compostos por rochas. Todas as demais colunas têm fustes de concreto. Na imagem de 1929,78 a coluna de pedra mais ao norte (lado leste) aparece com o fuste rompido ao meio. Como a coluna atual está íntegra, sem emenda no fuste, deduz-se que sua construção é, portanto, posterior a 1929. As colunas que ladeiam o dístico são, assim como essa, compostas por granada-biotita gnaisse porfiroclástico. Todavia, a coluna à esquerda do dístico apresenta uma peculiaridade: o capitel e a pinha são lavrados em um único bloco de rocha, enquanto nas demais essas são peças individuais (Figura 30). Em imagem de O Globo $0^{79}$ de 1963, o fuste, o capitel e a pinha dessa coluna estão ausentes, o que indica ter sido a peça em monobloco produzida depois dessa data. A coluna à direita do dístico, por sua vez, apresenta cicatriz de ruptura no suporte (Figura 31 ), logo abaixo da pinha. Essa coluna, assim como 
a situada na entrada norte, foi retirada com a utilização de um caminhão-guincho durante tentativa de roubo ocorrida em 2005, quando, além da remoção das colunas, partes das muretas foram quebradas. $O$ cimento utilizado na fixação da ruptura do suporte, contudo, tem as mesmas características texturais e mineralógicas daquele utilizado no reparo da fita granítica, indicando que o rompimento e o restauro são anteriores ao vandalismo de 2005.
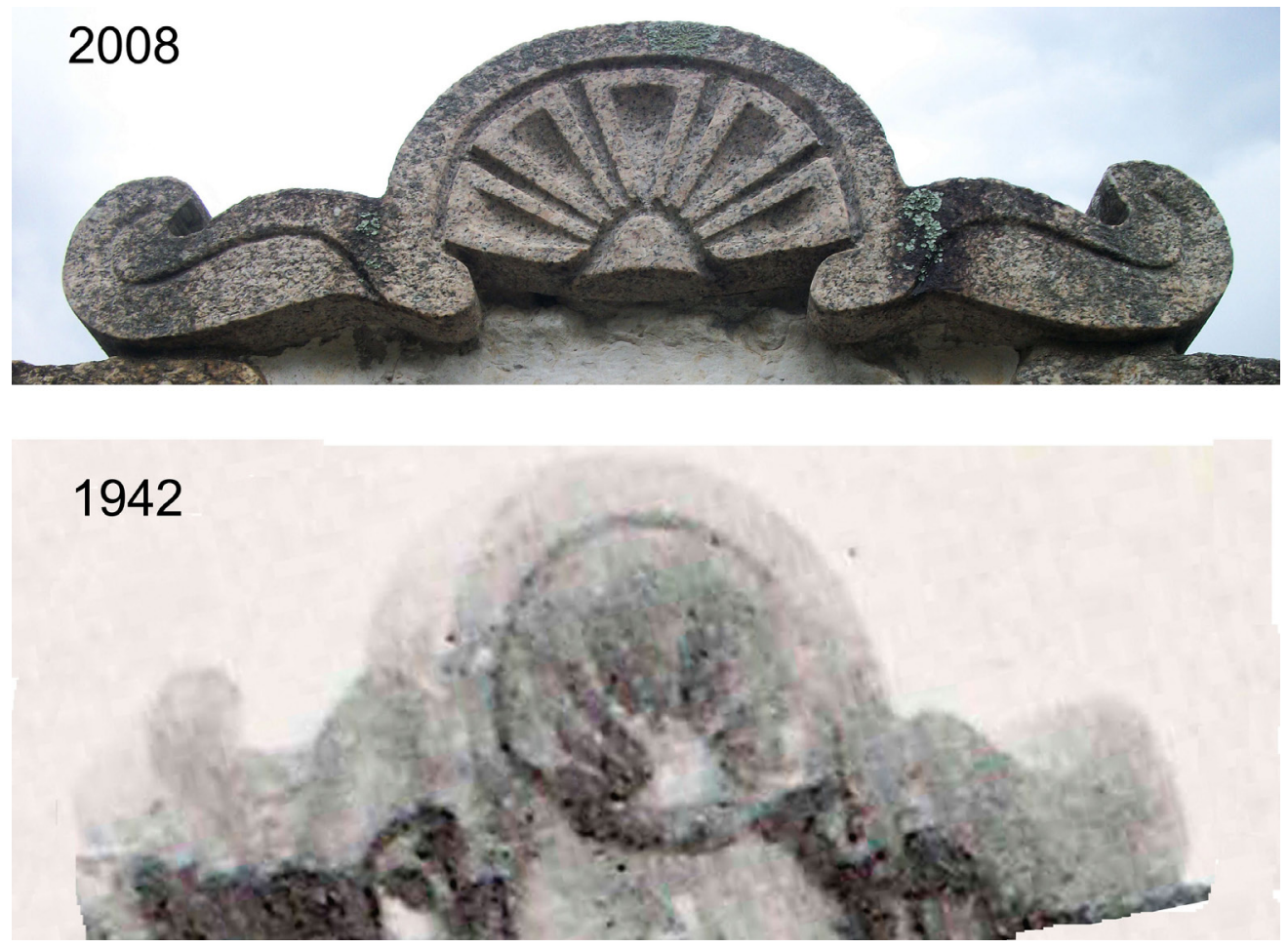

Figura 29 - Escultura que ornamenta o topo do dístico. No topo, imagem atual (fotografia da autora, 2018). Abaixo, imagem de Goes (1942).

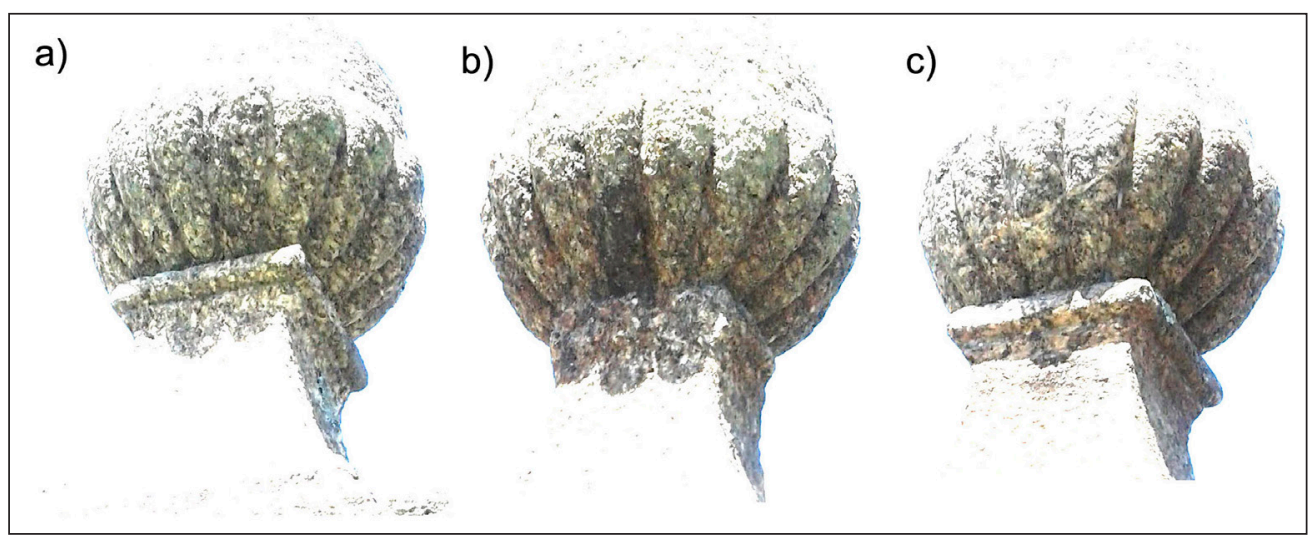

Figura 30 - Detalhe das pinhas das colunas de pedra: (a) coluna da entrada norte, lado, leste; (b) coluna à esquerda do dístico; e c) coluna à direita do dístico. Fotografia da autora (2018). 
80. Padberg-Drenkpol (1937)

Figura 31 - No topo, marca de ruptura em coluna situada à esquerda do dístico. Abaixo, detathe do cimento utilizado no restauro. Fotografia da autora (2018).
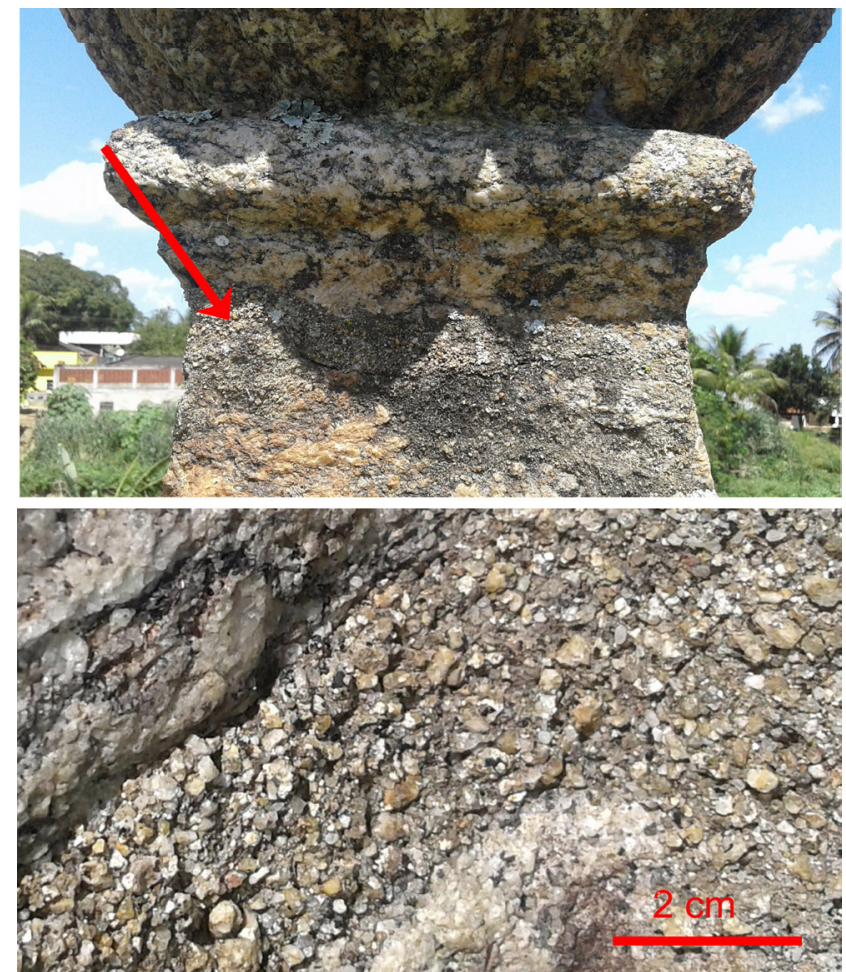

As pinhas e os capitéis das colunas cujos fustes são de concreto foram esculpidos em granodiorito equigranular de granulação grossa (Figura 32), rochas sem equivalentes nas pedreiras de Santa Cruz. As imagens revelam que, entre 1963 e 1984, todas as colunas de concreto tiveram suas pinhas retiradas. Essas são vistas novamente nas imagens a partir de 1989, sendo provável, portanto, que as peças em granodiorito tenham sido produzidas durante o projeto de recuperação levado a cabo pelo Departamento de Parques e Jardins em 1985.

Em nossa pesquisa não foram encontrados os encaixes por onde corriam as comportas, vistos por Padberg-Drenkpo 80 nos anos 1930. Também não foram localizadas imagens que as ilustrem, provavelmente porque a face a montante, com suas comportas, talhantes, correntes e registros, não apresentava a mesma harmonia estética da face a jusante. $\bigcirc$ equilíbrio também seria afetado por dois arcos na entrada leste do vão mais amplo, acima dos quais se observa uma arruela esculpida em granada-biotita gnaisse porfiroclástico (Figura 33). Rente ao solo, confrontando os portais, há uma cantaria triangular, também em gnaisse. A forma e a posição dessas peças sugerem tratar-se de elementos integrantes do sistema de comportas instaladas nos arcos laterais, sendo o triângulo, provavelmente, um mecanismo de trava. 


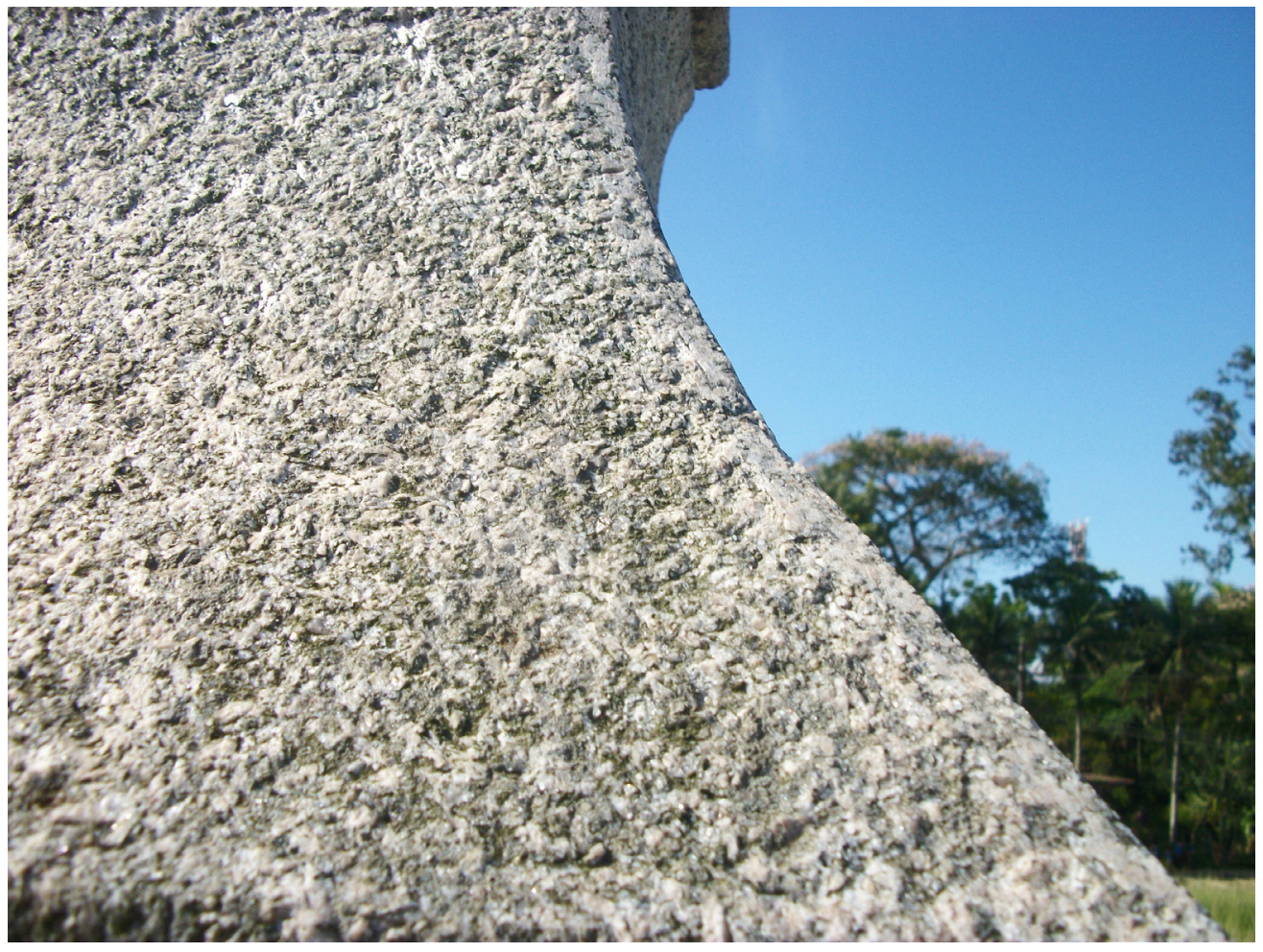

Figura 32 - Cantaria em granodiorito de granulação grossa utilizado na composição de pinhas que ornam as colunas de concreto. Fotografia da autora (2018).

Há, no encontro dos talhantes com a ponte, faixas estreitas revestidas por blocos irregulares de rochas unidos por cimento e que podem representar cicatrizes de antigos encaixes das comportas (Figura 33). Em um dos arcos medianos foi observada uma cantaria de arremate na junção do talhante com a pilastra (Figura 34). Peças semelhantes, de formato prismático e base triangular, foram encontradas no interior de um dos túneis, sugerindo que, no passado, as junções teriam sido protegidas por tal material (Figura 35).

À esquerda da entrada sul da ponte, uma abertura no piso do tabuleiro dá acesso a uma escadaria de cinco degraus que se projeta na direção de um dos talhantes, conduzindo a um vão com aproximadamente dois metros de altura, no qual um homem, de braços fechados, pode permanecer em pé. $\bigcirc$ espaço estreito é totalmente bloqueado por cantarias, à exceção de uma abertura retangular junto ao solo, com menos de $20 \mathrm{~cm}$ de altura, semelhante a uma chicana, e que permite o escoamento da água pluvial (Figura 36). Entre a população há a crença, fortalecida pela mídia, de que tal abertura seria a entrada de um túnel que liga o antigo mosteiro à ponte. ${ }^{81}$ Em edição de $\bigcirc$ Globo de 1929, a Diretoria do
81. Cf. Viana (1965); Patrimônio (1967); Um Mistério (1988); NOPH (1992); Ponte (1993) 
Figura 33 - Estruturas em cantaria que integram o mecanismo de comportas na entrada oeste do túnel sul. Em (b), detalhe da arruela. Em (c), vista superior da cantaria triangular. Fotografia da autora (2018).

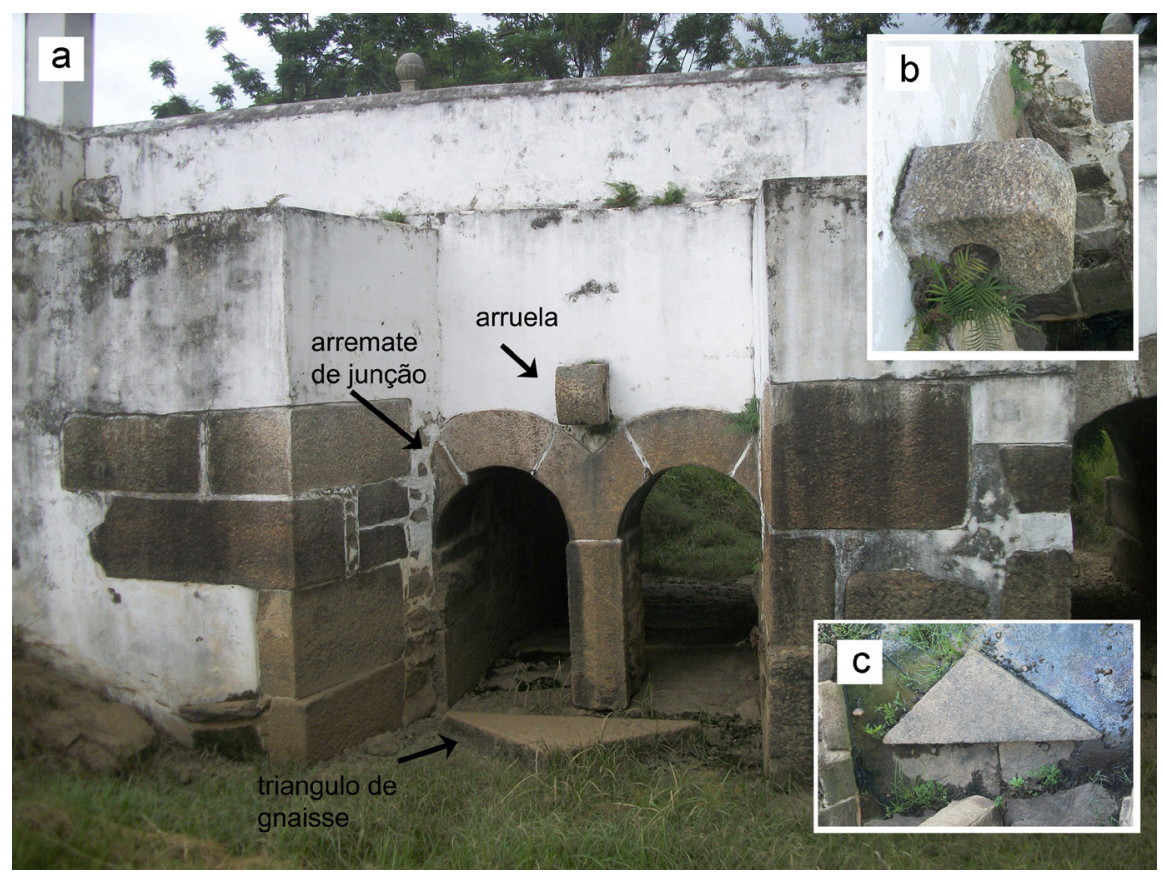

Figura 34 - Cantaria de arremate da junção entre parede e talhante. Fotografia da autora (2018).

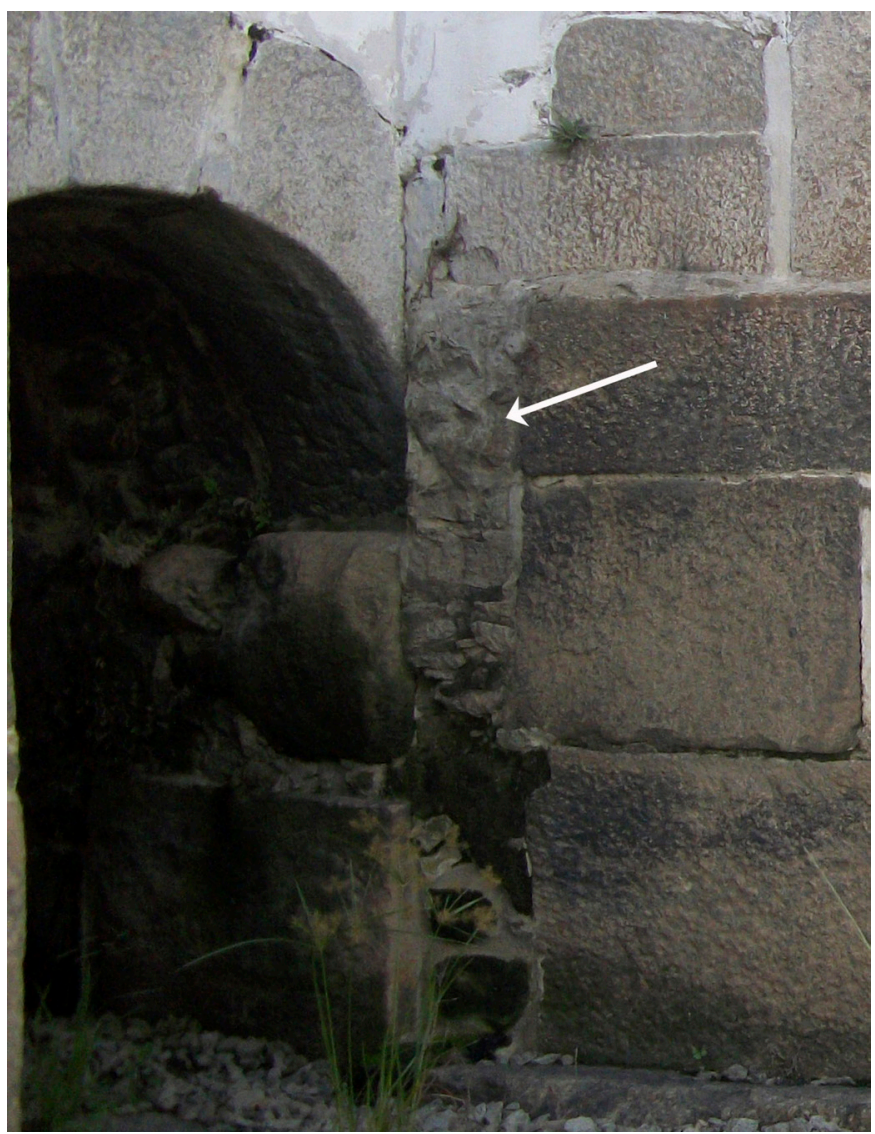


Patrimônio esclarece que a abertura era uma "passagem para os padres tomarem banho", então bloqueada pela queda de um bloco. ${ }^{82}$ Freitas também afirma que a ponte era dotada de uma escada de pedra pela qual se tinha acesso a uma área de banho, utilizada quando as comportas estavam fechadas. ${ }^{83}$ Por fim, a empresa responsável pelo restauro da ponte em 2005 registra em sua relação de obras "a limpeza da escada de acesso a uma das galerias". ${ }^{84}$

Características observadas em campo favorecem a hipótese de que a escada seria via de acesso a uma área de banho, pois o túnel sul é o de maior dimensão, e o único com piso lajeado e arcos duplos a montante (Figura 37), compondo dessa forma uma banheira segura. Embora não exista vestígio de antiga passagem nas paredes do túnel, é possível que houvesse uma saída lateral - talvez a discreta abertura ao lado do arco que pode ser vista na gravura de Niemeyer (Figura 38). Estudos geofísicos estão sendo realizados com o objetivo de investigar a morfologia desse vão.

As cantarias que revestem o interior dos túneis são almofadadas (Figura 39). Comum em pontes romanas, esse tipo de cantaria é encontrado em várias pontes de pedra portuguesas. ${ }^{85}$ Como a parte mais frágil da cantaria está nas zonas de juntas, o estofamento da rocha faz que essas zonas fiquem protegidas pela almofada, pois passam para um segundo plano em relação à superfície principal, reduzindo o atrito na região mais sensível. ${ }^{86}$

Em um dos arcos centrais foi observada uma cantaria de quina arredondada, com duas perfurações (Figura 40). Essa peça, única com tal formato e feição, talvez tenha funcionado como ponto de amarra de barcos.

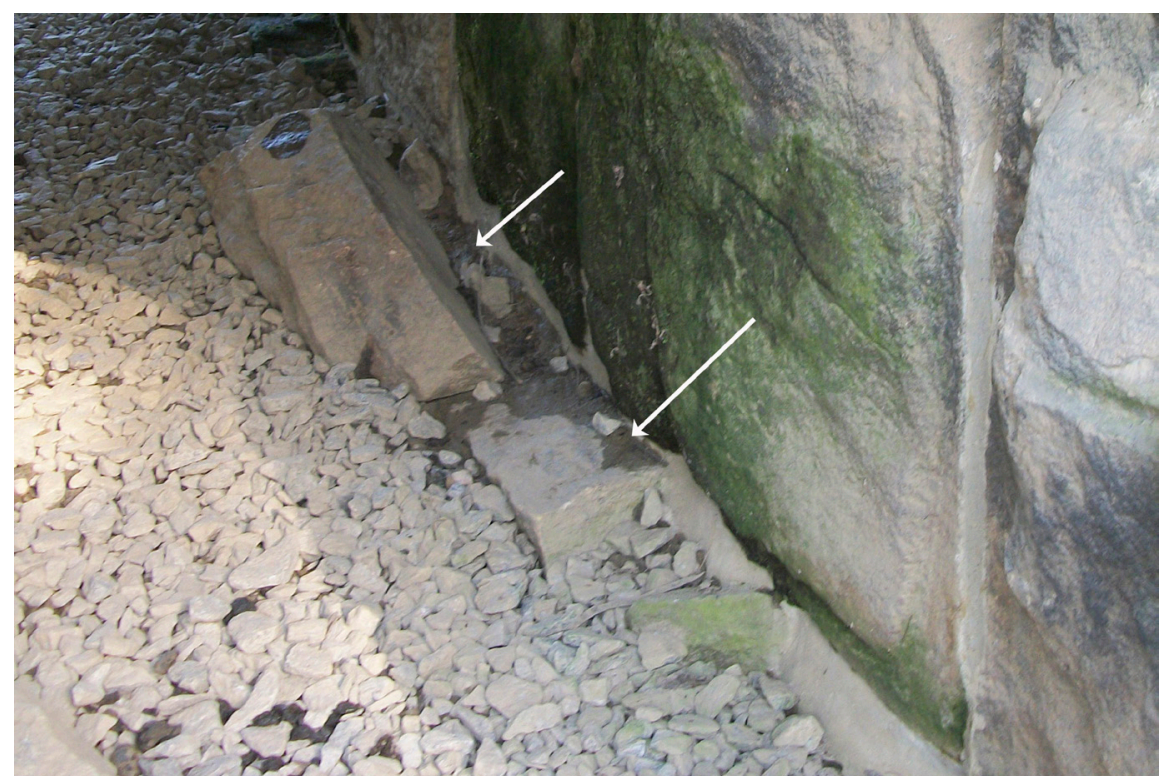

82. Será (1963).

83. Freitas (1985a).

84. Restauro (2018).

85. Cf. A Brief Description (2017).

86. Ibid. (2017).definamos alguns termos: os campos são subdivisões de um sistema de registro (neste caso, a ficha catalográfica) que contêm uma informação definida sobre o objeto de museu, por exemplo, nome do autor, nome do objeto (Cidoc; Icom, 2014). Já os metadados são explicações e descrições dos campos que orientam tanto o pesquisador que elabora a ficha quanto quem a consulta (Mey; Silveira, 2009 apud Tabosa; Paes, 2012).
Figura $35-$ Pe- $^{-}$ ças de cantaria encontradas no interior do vão do túnel. Foto da autora (2018). 
Figura $36-(a)$ Abertura de acesso a vão sob o tabuleiro; (b, c) vista em planta da mesma abertura; (d) vista interna. Foto da autora (2018).

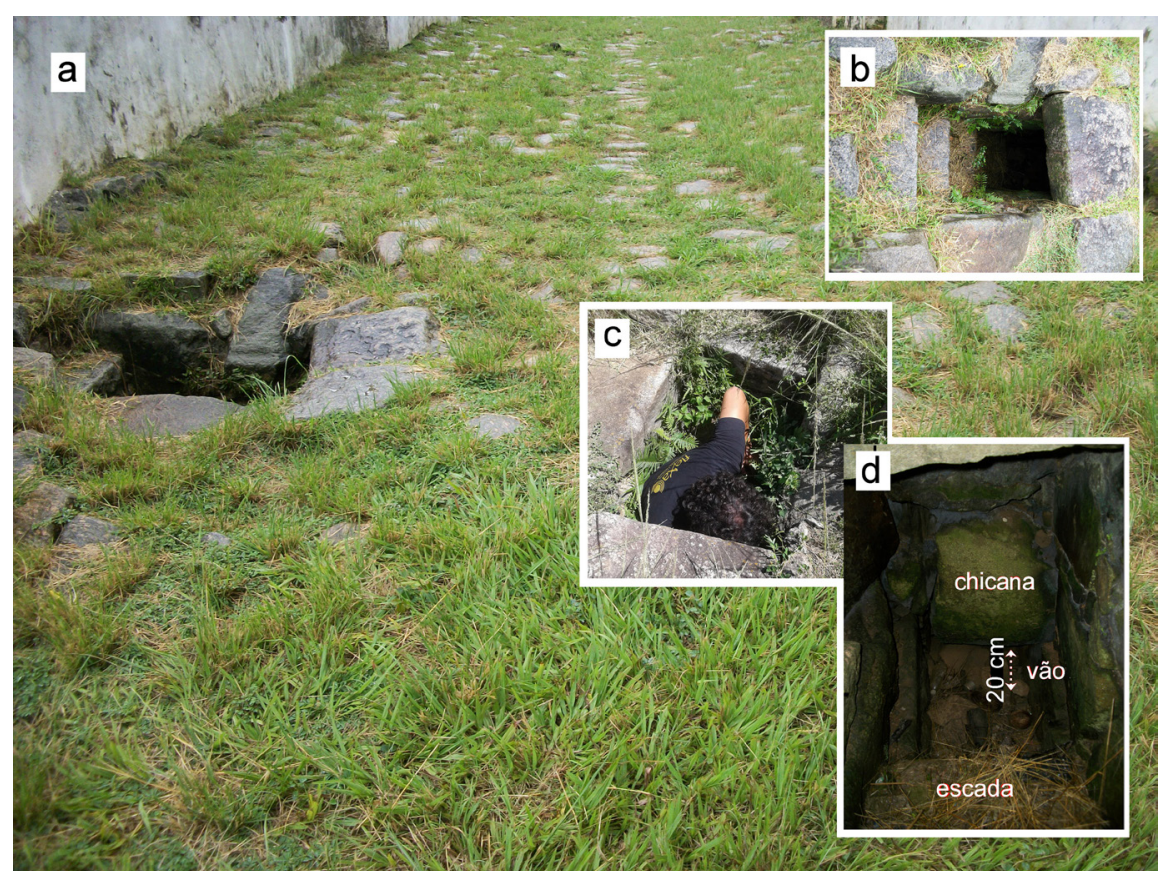

Figura 37 - Pavimento em lajes de cantaria no interior do tú nel sul. Foto da autora (2018).

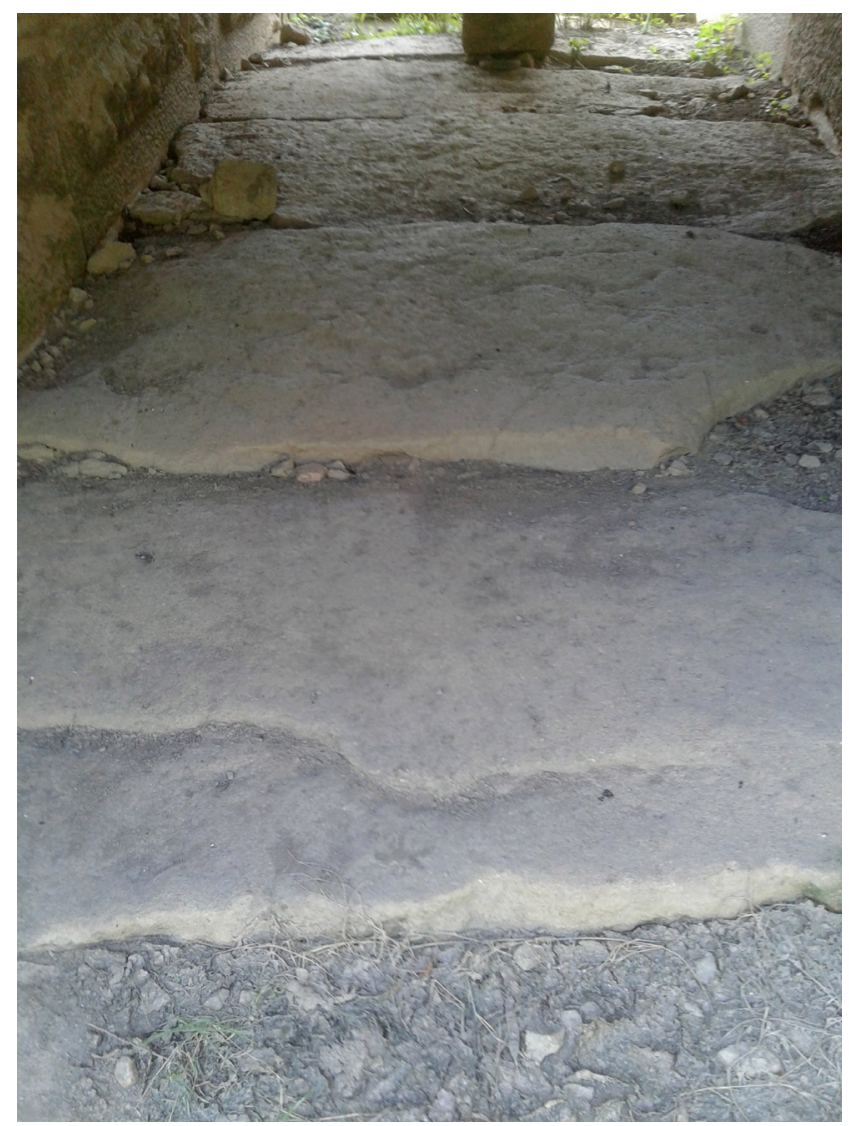




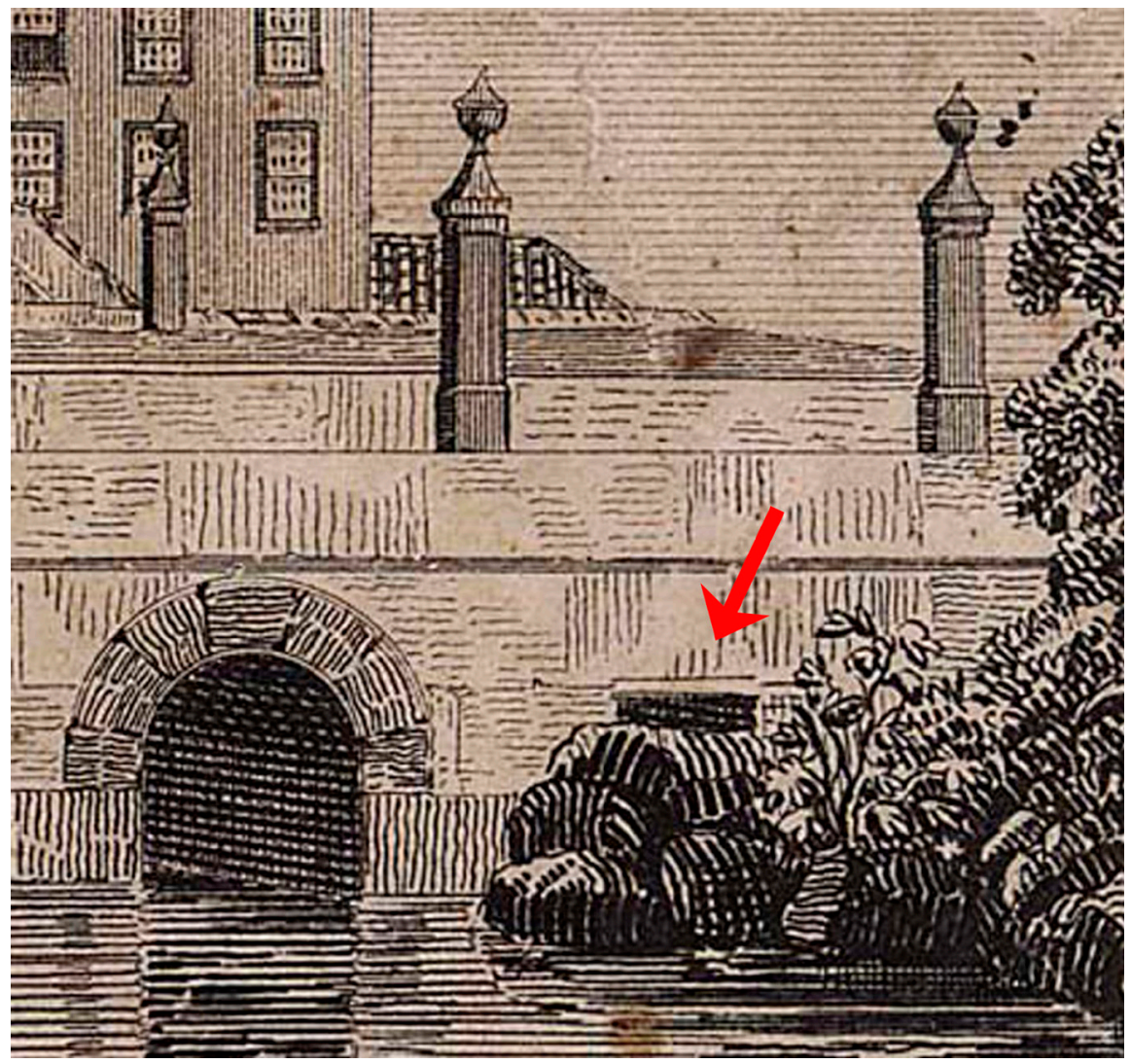

Figura 38 Detalhe da imagem de Conrado Jacob Niemeyer com indicação de abertura lateral ao túnel sul. Fonte: Niemeyer (1948).

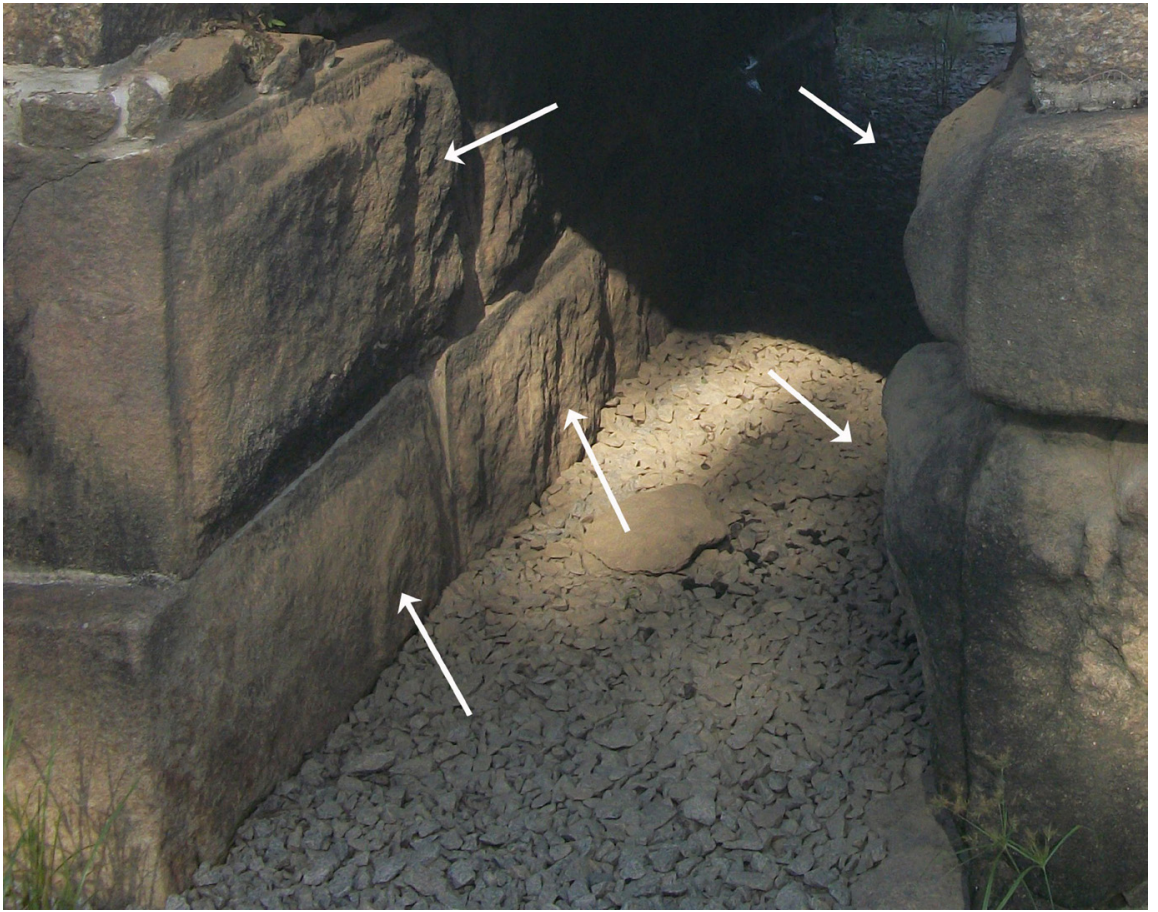

Figura 39 - Revestimento em cantaria almofadada em parede de vão. Foto da autora (2018). 
Figura $40-$ Provável ponto de amarra de barcos junto a entrada de um dos túneis centrais. Foto da autora (2018).

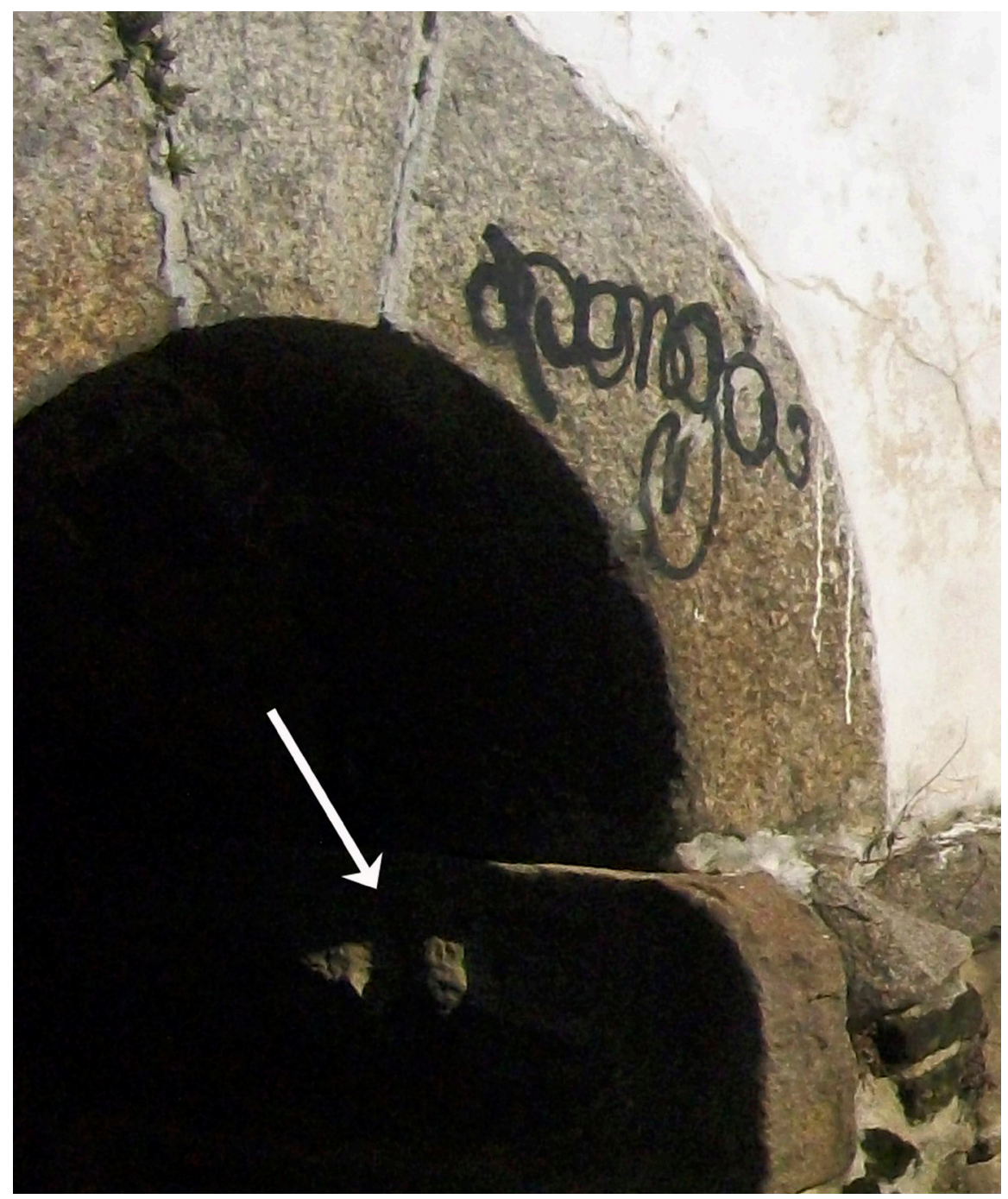

\section{CONSIDERAÇÕES FINAIS}

A mais antiga imagem da Ponte dos Jesuítas, produzida por Niemeyer em meados do século XIX, apresenta diferenças, em relação à configuração atual, no número de colunas, na forma das pinhas e do dístico e na extensão do parapeito. A precisão com que o autor retrata as distâncias entre colunas, assim como a desigualdade nas dimensões dos arcos, leva a crer que a 
representação seja autêntica, e não fruto de liberdade estética por parte do artista. $O$ dístico por ele retratado apresenta dimensões maiores que as do dístico atual, cuja base em cantaria escalonada é proporcional ao ornamento reproduzido pelo engenheiro. Tal disposição sugere ser o dístico contemporâneo o substituto de um ornamento anterior de maiores proporções. Entretanto, a menção de Manoel Martins do Couto Reis à frase latina, 44 anos antes da elaboração da imagem, revela que a peça lavrada em granito já existia em 1804. Uma possibilidade é ter sido o dístico original temporariamente substituído pelo conjunto ornado com a coroa imperial. A frase "enfeites da inscrição de pedra que tem de ser colocada na Ponte do Rio do Curtume", registrada no livro de pagamentos no ano anterior à produção da imagem, revela que a pedra, com os respectivos enfeites, "seria" levada à ponte. Além do mais, a estrutura na qual se apoia o dístico, nos dias atuais, é formada por blocos de rochas que se sobrepõem a uma cantaria (base não caiada da Figura 2) cujas proporções se equiparam à cantaria com a inscrição latina. Nessa hipótese, os blocos superiores teriam sido adicionados com o objetivo de ampliar a base de sustentação do ornamento retratado por Niemeyer.

A falta de registros iconográficos do dístico no período entre a representação de Niemeyer e a primeira fotografia, datada de 1925, não permite esclarecer essa questão, pois nesse ano o dístico já exibia a atual configuração, embora desprovido da escultura em forma de sol: base trabalhada em monobloco de allanita granito, sobreposta pelo brasão em calcário com o símbolo jesuítico ladeado por granada-biotita gnaisse porfiroclástico, cujo trabalho em alto-relevo dá continuidade às delicadas espirais desenhadas sobre - bloco inferior. É possível, contudo, que a cantaria lavrada em granito e o gnaisse não estivessem juntos na composição original. $\bigcirc$ registro textual informa que obras de restauração de maior envergadura ocorreram pelo menos em seis episódios (1 847, 1854, 1953, 1963, 1985 e 2008), e a análise petrográfica, assim como o registro iconográfico, atesta diferentes momentos de produção das cinco peças de cantaria do dístico e das oito colunas ornamentais. Dentre os elementos do dístico, apenas o brasão jesuítico é identificado na peça do século XVIII e em todas as demais imagens.

O reconhecimento de modificações na aparência dos adornos da Ponte dos Jesuítas, ao contrário de diminuir sua importância, acrescenta novos elementos de discussão, pois cada intervenção reflete um momento histórico. Espera-se, por fim, que o trabalho aqui apresentado sirva de estímulo a pesquisas na área de história da ciência e tecnologia no Brasil, pois, apesar de a superestrutura da ponte ter sido parcialmente modificada, saqueada e 
vandalizada, sua mesoestrutura, por estar submersa e, posteriormente, soterrada, foi quase totalmente preservada, permitindo o estudo da engenharia de construção utilizada no período.

\section{AGRADECIMENTOS}

Agradeço a Odalice Miranda Priosti (in memorian), Walter Priosti e Márcio Pinto, membros do Núcleo de Orientação e Pesquisa Histórica de Santa Cruz, pelo estímulo a esta pesquisa. Agradeço a Jair de Souza, da Companhia de Pesquisa de Recursos Minerais do Rio de Janeiro, pelo apoio na obtenção de imagens. 


\section{REFERÊNCIAS}

\section{FONTES IMPRESSAS}

COUTO REIS, Manuel Martins de. Memórias de Santa Cruz: seu estabelecimento e economia primitiva: seus sucessos mais notáveis, continuados do tempo da extinção dos denominados jesuítas, seus fundadores, até o ano de 1804: copiado de um manuscrito que existe na Biblioteca Pública desta Corte. Revista do Instituto Histórico e Geográfico Brasileiro, Rio de Janeiro, Tomo V, p. 154-199, 1885.

DEGRADAÇÃO também causada por vandalismo. O Globo, Rio de Janeiro, 2006, 15 out. 2006. Caderno Zona Oeste.

DESPREZO pela história é comum. O Globo, Rio de Janeiro, p. 4, 2 jul. 2006.

A FAZENDA de Santa Cruz. Revista da Semana, Rio de Janeiro, ano XXXIV, n. 19, p. 21-22, 22 abr. 1933. Disponível em: <https://bit.ly/2SScGcA>. Acesso em: 14 jan. 2019.

HELMBOLD, Reinhard; VALENÇA, Joel Gomes; LEONARDO JR., Otho Henrique. Mapa geológico do estado da Guanabara. Brasília, DF: Ministério de Minas e Energia/Departamento Nacional de Produção Mineral, 1965. 3 folhas. Escala. 1:50.000.

MEMÓRIA preservada em Santa Cruz: após atos de vandalismo Ponte dos Jesuítas é reformada. E fonte Wallace recebe conservação. O Globo, Rio de Janeiro, p. 6, 13 jul. 2008. Caderno Zona Oeste.

MINISTÉRIO DO EXÉRCITO. Folha topográfica Santa Cruz, escala 1:50.000. Brasília, DF: Departamento de Engenharia e Comunicação, 1987.

UM MISTÉRIO de 200 anos. O Globo, Rio de Janeiro, p. 44, 21 ago. 1988. Edição Matutina, Jornais de Bairro.

O MODERNISMO iconoclasta: ameaçada de demolição uma ponte histórica. $O$ Globo, Rio de Janeiro, p. 3, 16 out. 1931. Geral.

MONUMENTO a Marechal Deodoro é dilapidado por ladrões de metais. O Globo, Rio de Janeiro, p. 11, 1985. Edição Matutina, Rio. 
NIEMEYER, Conrado Jacob. 1788-1862. Planta corographica de huma parte da provincia do Rio de Janeiro na qual se inclue a Imperial Fazenda de Santa Cruz. 1848. 1 planta 41 x 22 $\mathrm{cm}$ em folha de $50 \times 56 \mathrm{~cm}$. Escala 1:200.000. Litografia de Heaton e Rensburg. Acervo da Biblioteca Nacional.

NOPH quer providências para ponte histórica. O Globo, Rio de Janeiro, p. 28, 29 mar. 1992. Caderno Zona Oeste.

OBRAS adiadas e problemas sem solução. O Globo, Rio de Janeiro, p. 5, 1 jan. 2006. Caderno Zona Oeste.

PATRIMÔNIO foi ver a Ponte dos Jesuítas. O Globo, Rio de Janeiro, p. 3, 26 abr. 1967. Edição Matutina, Geral, Rio de Bairro em Bairro.

PATRIMÔNIO vai restaurar solar d'El Rey e ponte. O Globo, Rio de Janeiro, p. 5, 4 jul. 1972. Edição Matutina, Geral.

A PONTE dos depredadores. O Globo, Rio de Janeiro, p. 3, 11 nov. 1971. Edição Matutina, Geral.

PONTE dos Jesuítas aguarda restauração. O Globo, Rio de Janeiro, p. 3, 15 abr. 2006. Caderno Zona Oeste.

A PONTE dos Jesuítas está de cara nova. O Globo, Rio de Janeiro, p. 2, 29 fev. 2004a. Caderno Zona Oeste.

PONTE dos Jesuítas é limpa e reformada. O Globo, Rio de Janeiro, p. 3, 21 nov. 2004b. Caderno Zona Oeste.

PONTE dos Jesuítas é restaurada. O Globo, Rio de Janeiro, p. 6, 2 set. 2007. Caderno Zona Oeste.

PONTE dos Jesuítas: obra exemplar guarda mistério em Santa Cruz. O Globo, Rio de Janeiro, p. 6, 24 out. 1993. Edição Matutina, Caderno Zona Oeste.

A PONTE que ia ser atração. O Globo, Rio de Janeiro, p. 3, 4 abr. 1967. Edição Matutina, Geral.

PONTE tombada é alvo de ladrões. O Globo, Rio de Janeiro, p. 22, 17 abr. 2005. Caderno Zona Oeste. 
PRAÇA 15 voltará a ser o Largo do Paço. O Globo, Rio de Janeiro, p. 15, 7 ago. 1980. Edição Matutina, Rio.

QUERUBINS ficam 45 dias longe da praça. O Globo, Rio de Janeiro, p. 28, 1985. Edição Matutina, Rio.

RECUPERAÇÃO sem atalhos. O Globo, Rio de Janeiro, p. 12-13, 1 maio 2005. Caderno Zona Oeste.

O RESGATE do foro em Santa Cruz: uma questão palpitante para os antigos moradores da Fazenda Imperial. O Globo, Rio de Janeiro, p. 8, 7 out. 1927. Edição Matutina, Geral.

SERÁ atração turística a Ponte dos Jesuítas. O Globo, Rio de Janeiro, p. 2, 31 jul. 1963. Edição Matutina, Geral.

\section{LIVROS, ARTIGOS E TESES}

ABREU, Sylvio Froes. O Distrito Federal e seus recursos naturais. Rio de Janeiro: IBGE, 1957. (Biblioteca Geográfica Brasileira, série A, v. 14).

ALMEIDA, Soraya. Reconhecimento da mineração como atividade relevante na história da Fazenda Santa Cruz. In: SIMPÓSIO BRASILEIRO DE PATRIMÔNIO GEOLÓGICO, 3., 2005, Lençóis. Anais [...]. Feira de Santana: UEFS, 2015. p. 541-544.

ALONSO, Delnilda Martinez. Alguns aspectos geográficos do município de Itaguaí. Revista Brasileira de Geografia, Rio de Janeiro, v. 22, n. 3, p. 381-432, 1960.

AMARAL, Prudêncio do; MELO, José Rodrigues. Geórgicas brasileiras (Cantos sobre coisas rusticas do Brasil) 1781. Rio de Janeiro: Academia Brasileira de Letras, 1941.

BAEDECKER, Phillip; REDDY, Michel. The erosion of carbonate stone by acid rain: laboratory and field investigations. Journal of Chemical Education, Washington, DC, v. 70, n. 2, p. 104108, 1993.

BASTOS, Ibere. Os jesuítas e a Fazenda de Santa Cruz: a sesmaria de Christovan Monteiro: o primeiro conservatório do Brasil: apontamentos de um repórter. Revista da Semana, Rio de Janeiro, ano XLI, n. 43, p. 14-15. 1940.

CARRAZZONI, Maria Elisa. Guia dos bens tombados. Rio de Janeiro: Expressão e Cultura, 1987. 
CORDEIRO, Pedro Nuno Morgado Marques. Pontes de pedra: estudo de um caso prático. 2014. 121 f. Dissertação (Mestrado) - Escola Superior de Tecnologia e Gestão de Viseu, Viseu, 2014.

CORRÊA, Magalhães. Terra carioca: fontes e chafarizes. Rio de Janeiro: Imprensa Nacional, 1939. (Coleção Memória do Rio).

COSTA, Pedro Miguel Quintela Marques da. Análise da construção e do comportamento duma ponte de pedra. 2007. 399 f. Dissertação (Mestrado) - Faculdade de Engenharia da Universidade do Porto, Porto, 2007.

FARIA, Luciana Alves; ALMEIDA, Soraya. Rochas do Matadouro Imperial de Santa Cruz, Rio de Janeiro: pedras que revelam o passado histórico e geológico. In: Seminário Nacional de História da Ciência e da Tecnologia, 15., 2016, Florianópolis. Anais [...]. Rio de Janeiro: Sociedade Brasileira de História da Ciência, 2016. Disponível em <https://goo.gl/hLscTc>. Acesso em: 14 jan. 2019.

FERREIRA, Vieira. Antigas inscrições do Rio de Janeiro e Niterói. Revista do Instituto Histórico Geográfico Brasileiro, Rio de Janeiro, tomo 106, v. 160, p. 29-122, 1929.

FREITAS, Benedicto. História de Santa Cruz: a era jesuítica (1567-1759). Rio de Janeiro, 1985a. v. 1.

FREITAS, Benedicto. História de Santa Cruz: vice-rei e reinado (1760-1821). Rio de Janeiro: 1985b. v. 2.

FRIEDMAN, Fania. Donos do Rio em nome do Rei: uma história fundiária da cidade do Rio de Janeiro. Rio de Janeiro: Zahar; Garamond, 1999.

GAMA, José de Saldanha da. História da Fazenda Imperial de Santa Cruz. Revista do Instituto Histórico Geográfico Brasileiro, tomo 38, p. 165-230, 1875.

GOES, Hildebrando de Araújo. A Baixada de Sepetiba. Imprensa Nacional: Rio de Janeiro, 1942.

GUIMARÃES, Antônio. Uma obra de gênio: Companhia de Jesus. Revista da Semana, Rio de Janeiro, ano XLI, n. 43, p. 16-17, 26 out. 1940. Disponível em: https://bit.ly/2ANUwSd. Acesso em: 14 jan. 2019.

JESUS, João Jorge Carrazedo de. Caraterização geométrico-estrutural de pontes em arco de alvenaria na região de Bragança. 2013. 174 f. Dissertação (Mestrado) - Escola Superior de Tecnologia e Gestão Instituto Politécnico de Bragança, Bragança, 2013. 
LIVRO histórico. Rio de Janeiro: Instituto do Patrimônio Histórico e Artístico Nacional, 1938. Inscrição: 003. Data: 5-4-1938. No Processo: 0100-T-38.

MANSUR, André Luiz; MORAIS, Ronaldo. Fragmentos do Rio Antigo. Rio de Janeiro: Edital, 2014.

MORAIS FILHO, Mello Alexandre José. Quadros e chronicas: com um "estudo" por Sylvio Romero. Rio de Janeiro: H. Garnier, [18--?].

NETTO, Américo. A viagem da comissão de estudos da A.E.R.: impressões de viagem publicadas no Estado de São Paulo em 1925. DERRON, Donald; NETTO, Américo. Estrada São Paulo-Rio. São Paulo: Associação de Estradas de Rodagem, 1927. São Paulo. p. 129-165.

PADBERG-DRENKPOL, Augusto. Recordações históricas do Rio através de velhas inscrições latinas: dois dísticos dos antigos jesuítas do Rio e um epitáfio memorável. Boletim do Centro de Estudos Históricos, ano II, fascículo II, tomo II, p. 18-25, 1937.

PIRES, Fernando Roberto Mendes; VALENÇA, Joel Gomes; RIBEIRO, André. Multistage generation of granite in Rio de Janeiro, Brazil. Anais Academia Brasileira de Ciências, v. 54, n. 3, p. 563-574, 1982.

SILVA, Moacir. Kilometro zero: caminhos antigos, estradas modernas: rodovias cariocas, irradiação rodoviária do Rio de Janeiro. Rio de Janeiro: [s. n.], 1934.

SILVA, Regina Pirajá. Biografias. In: AMARAL, Prudêncio do; MELO, José Rodrigues. Geórgicas brasileiras: cantos sobre coisas rústicas do Brasil (1781). Rio de Janeiro: Publicações da Academia Brasileira, 1941.

SOZIM, Raul José; ZAN, Sérgio Monteiro. Introdução. In: AMARAL, Prudêncio do; MELO, José Rodrigues. De rvsticis brasiliae rebvs: temas rurais do Brasil. Tradução: Raul José Sozim e Sérgio Monteiro Zan. Ponta Grossa: Editora UEPG, 1997. Edição bilíngue.

VIANA, Marfa Barbosa. Antiga Fazenda Real de Santa Cruz: um pouco de histórias e lendas. Anais do Museu Histórico Nacional, Rio de Janeiro, v. 15, p. 267-275, 1965.

SITES

A BRIEF DESCRIPTION of the main Roman masonry techniques: 1st. part. Aeternitas Numismatics, [S. 1.], 23 nov. 2017. Disponível em: <https://bit.ly/2iIGp7R>. Acesso em: 24 jul. 2018. 
PONTE dos Jesuítas - Santa Cruz. Prefeitura do Rio de Janeiro, Rio de Janeiro, 2008. Disponível em: <https://goo.gl/vDoMG4>. Acesso em: 12 abr. 2016.

RESTAURO da Ponte dos Jesuítas - Campo Grande/RJ. Grupo PGG, São Paulo, 2018. Disponível em: <https://bit.ly/2RLbyds>. Acesso em: 26 jul. 2018.

Artigo apresentado em 28/08/2018. Aprovado em 05/12/2018.

\section{(cc) BY}

All the contents of this journal, except where otherwise noted, is licensed under a Creative Commons Attribution License 